\title{
"Continua a febre dos monumentos": a estatuomania na imprensa do Rio de Janeiro (décadas de 1880 a 1930)
}

"Continua a febre dos monumentos": The statuomanie in the Rio de Janeiro (Brazil) press (1880s-1930s)

hitps://doi.org/10.1590/1982-02672021v29e60

\section{RAFAEL DIAS SCARELLI'}

hitps: / / orcid. org/0000-0002-6103-6539

Universidade de São Paulo / São Paulo, SP, Brasil

RESUMO: Este artigo aborda como a imprensa carioca e os intelectuais da época perceberam e analisaram a expansão da escultura pública na cidade do Rio de Janeiro entre as décadas de 1880 e 1930. Em especial, investiga como esses atores se apropriaram da ideia de "estatuomania", a partir da observação atenta do que se passava na França, para interpretar a realidade urbana carioca. Defendemos que não se tratou da simples "importação" de uma ideia estranha ao meio local, mas, sim, de um processo de intensa reelaboração e adaptação do conceito, mobilizando-o no bojo das disputas político-ideológicas do momento. Para tal análise, apoiamo-nos, como fontes documentais, nos artigos publicados nos jornais e revistas ilustradas da então capital brasileira, além de periódicos franceses.

PALAVRAS-CHAVE: Estatuomania. Estátuas. Imprensa. Rio de Janeiro.

ABSTRACT: This article discusses how the carioca press and intellectuals understood and analyzed the expansion of public sculpture in the city of Rio de Janeiro, Brazil, between the 1880s and the 1930s. It aims to investigate how these actors appropriated the idea of "statuomanie", interpreting the carioca urban reality in the light of what was happening in France. This article argues that it was not a mere "importation" of a foreign idea to the local environment, but

\begin{abstract}
1. Doutorando do Programa de Pós-Graduação em História Social da Universidade de São Paulo (USP). Desenvolve pesquisa com financiamento da Fapesp (Fundação de Amparo à Pesquisa do Estado de São Paulo) (processo $\mathrm{n}^{\circ}$ 2020/05096-0). As opiniões, hipóteses e conclusões ou recomendações expressas neste material são de responsabilidade do autor e não necessariamente refletem a visão da Fapesp. E-mail: <rafael. scarelli@usp.br>.
\end{abstract}


rather a process of intense reworking and adaptation of the concept according to the context of political and ideological conflicts at the time. These analyses were conducted with data collected by means of documentary sources such as articles published in newspapers and illustrated magazines in Rio de Janeiro, as well as in the French press.

KEYWORDS: Statuomanie. Statues. Press. Rio de Janeiro. 


\section{INTRODUÇÃO}

Cartas Parisienses: Continua a febre dos monumentos. Daqui a pouco não teremos um palmo de território vazio, sem que logo seja ocupado por uma estátua a qualquer cidadão ilustre... ou desconhecido. Desta feita é o marechal Canrobert quem vai ser fundido em bronze. A França realmente sabe honrar a memória dos seus filhos e quer conservar as suas feições, tornar as suas cidades, ruas e casas como uma espécie de museu histórico e de recordações: nas casas onde nascem ou morrem os grandes cidadãos, as municipalidades mandam colocar uma lápide comemorativa. Quem quiser fazer um curso regular de história francesa, basta passear [por] Paris. Garanto que ao chegar ao fim do passeio terá aprendido mais do que se tivesse lido todos os tratados publicados até hoje. É, sem dúvida, de grande vantagem este curso de história escrito na pedra e no bronze. ${ }^{2}$

Como revela o texto publicado no diário Correio Paulistano em 13 de outubro de 1895 e assinado por "P. Vieira", no Brasil acompanhava-se com interesse a multiplicação de monumentos comemorativos na França. Contudo, nem todos os comentários publicados sobre esse tema nos dois países tiveram o mesmo entusiasmo e o mesmo tom elogioso assumido por Vieira. Ao mesmo tempo em que difundiam-se estátuas pelas grandes cidades do mundo ocidental desde fins do século XIX, erguiam-se vozes que denunciavam esse movimento como uma statuomanie, uma "mania das estátuas".

Este artigo se propõe a analisar como intelectuais da virada do século XIX para o XX percebiam e interpretavam a difusão da escultura pública no espaço urbano do Rio de Janeiro, analisando as publicações sobre o tema na imprensa carioca do período. Em especial, buscamos investigar como foi mobilizada a ideia de "estatuomania"3 entre os crítico da proliferação dos monumentos para se referir a esse fenômeno e caracterizar essa "febre" monumental.

artigo aborda a circulação de ideias e de conceitos, matizando a compreensão de que os intelectuais brasileiros teriam apenas copiado ou sofrido influência do exterior, especialmente do que era publicado na França. Nesse sentido, por um lado, buscamos demonstrar como o tema da proliferação das estátuas foi refletido a partir de interesses e disputas locais, manejando a ideia de estatuomania para pôr em discussão a legitimidade de homenagens em termos político-ideológicos; por outro lado, mostramos que esse debate não era uma simples "importação" de ideias completamente alheias ao Brasil do período, mas sim que, apesar de não vivenciar uma expansão da escultura pública semelhante à francesa, viu surgir diversos projetos escultóricos entre o final do século XIX e o princípio do século XX que aos poucos transformaram a fisionomia das principais cidades do país.
2. Cf. Vieira (1895, p. 1, grifo nosso).

3. Optamos pelo termo "estatuomania", ao invés de "statuomanie", porque foi dessa forma que esses intelectuais e periódicos se referiram ao fenômeno nos jornais brasileiros. 
4. Agulhon (1988).

5. Vanegas Carrasco (2011).

6. Ibid., p. 29-30. Traduzimos para o português apenas as citações em francês.

7. Diz o autor: "Sendo esta espécie tão depreciada quanto abundante, conservamos, para falar dela, o termo pejorativo, mas já tradicional, de statuomanie, ainda que o presente artigo se proponha a atenuar um pouco o desprezo por uma melhor compreensão histórica”. Agulhon, op. cit., p. 137-138. (No original: "Cette espèce étant aussi décriée qu'elle est abondante, nous avons conservé, pour en parler, le terme péjoratif mais déjà traditionnel de statuomanie, même si le présent article se propose d'atténuer un peu le mépris par une meilleure compréhension historique").
O historiador francês Maurice Agulhon é autor de trabalhos que se tornaram clássicos para a análise do tema da statuomanie, como Imagerie civique et décor urbain e La statuomanie et l'histoire, publicados na revista Ethnologie Française em 1975 e 1978, posteriormente reunidos no primeiro volume de Histoire Vagabonde. ${ }^{4}$ Contudo, a historiadora colombiana Carolina Vanegas Carrasco, em seu estudo sobre os monumentos a Simón Bolívar e Policarpa Salavarrieta em Bogotá, fez uma ponderação importante. Segundo ela, com muita frequência, trabalhos recentes atribuem o conceito de statuomanie a Maurice Agulhon, porém ele apenas o reintroduziu na década de $1970 .{ }^{5}$ O termo surgiu no próprio século XIX, para designar, com manifesto menosprezo, o fenômeno da difusão das estátuas pelas cidades. Sintetizou a autora:

Finalmente, tras la revolución de 1830 - y especialmente después de 1870, durante la Tercera República -, se produjo una aceleración del proceso conmemorativo por medio de estatuas que produjo el rechazo de sus contemporáneos, quienes ya desde la década de 1840 hablaban de 'estatuomanía' para referirse críticamente al aumento e instrumentalización indiscriminados de la producción de escultura conmemorativa. ${ }^{6}$

Dessa forma, a partir dos trabalhos de Agulhon, o termo statuomanie ganhou novo sentido na pesquisa histórica, passando a designar o próprio fenômeno de expansão da escultura pública desde o século XIX, sem carregar seu primitivo juízo depreciativo.? Por isso, ao mobilizarmos esse conceito devemos considerar sua dubiedade: tanto expressa o movimento de proliferação de homenagens escultóricas, que teve seu epicentro na França (primeiro durante a Monarquia de Julho, após a Revolução de 1830 e, especialmente, durante a Terceira República, desde o término da Guerra Franco-Prussiana (1870-1871), entrando em declínio após a Segunda Guerra Mundiall, quanto trata-se da forma como os críticos contemporâneos desse processo o nomearam e perceberam, implicando um incontornável juízo de valor.

A respeito das origens da expansão da escultura pública na França, Agulhon aponta o "humanismo liberal" como a ideologia implícita que the sustenta, demarcando o lugar originalmente conservador dos críticos à estatuomania. Durante - Antigo Regime, as homenagens escultóricas em espaço público eram reservadas aos reis e aos santos, de modo que estavam bloqueadas a quem não participasse da sacralidade monárquica ou religiosa-para essas pessoas, estavam destinadas as igrejas e os cemitérios, na qualidade de esculturas fúnebres, e o espaço privado. A multiplicação das estátuas só foi possível quando passaram a homenagear pessoas cujo mérito não era nem hereditário nem sacro, mas pessoal e laico. 
Houve, por assim dizer, uma "democratização" da estatuária, ainda que se direcionasse aos chamados "grandes homens". ${ }^{8}$ Nesse sentido, após a desagregação do Absolutismo, a imagem régia é substituída por monumentos a representações alegóricas e a indivíduos cujas trajetórias eram consideradas exemplares para "serem cultuados por seus pares cidadãos", por se destacarem em diversos âmbitos -cientistas, literatos, industriais etc. ${ }^{9}$

Nos países da América Latina, de maneira geral, a escultura pública se difundiu em um período posterior em relação à Europa. ${ }^{10}$ Os primeiros projetos escultóricos de maior envergadura - em especial, homenageando os heróis das lutas de independência e destinados às capitais nacionais - remontam a meados do século XIX, como as estátuas equestres a Simón Bolívar, em Lima (1859), "1 a

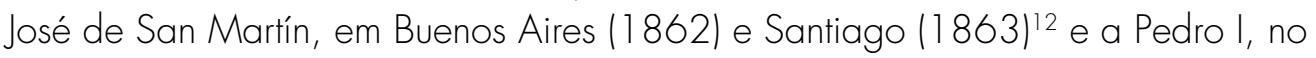
Rio de Janeiro (1862). ${ }^{13}$ Entretanto, é sobretudo nas primeiras décadas do século $X X$, embalada pelas comemorações dos centenários das independências nos mais diferentes países, entre os anos de 1908 e 1922, que a escultura pública vivenciará uma vertiginosa expansão na região. ${ }^{14}$ Nesse contexto, as autoridades públicas e as elites dirigentes responsáveis pelas encomendas dessas obras, por meio de concursos internacionais, buscavam, para além de cimentar as identidades nacionais, afirmar o caráter cosmopolita das suas cidades e o progresso alcançado após o primeiro século de vida independente. ${ }^{15}$

Desse modo, a estatuária se difunde na América Latina ao mesmo tempo em que, do outro lado do Atlântico, a statuomanie era intensamente denunciada, - que sem dúvida elucida a repercussão de discursos desse gênero por aqui, quando não possuíamos uma "população" de estátuas tão considerável. Seja como for, na passagem do século XIX ao XX, esse debate não se constituía em algo completamente alheio à nossa realidade, especialmente na então capital brasileira, o Rio de Janeiro, após a Proclamação da República, quando se intensificaram os esforços para forjar heróis e um imaginário para o novo regime. Nesse sentido, José Murilo de Carvalho, embora sublinhe os limites dessas iniciativas, reconhece que a encomenda e construção de estátuas cívicas foi um recurso mobilizado na luta política entre as diferentes correntes republicanas após o 15 de novembro, a exemplo dos positivistas. Afirma Carvalho:

A vertente positivista deixou a sua marca em vários monumentos republicanos, salientando-se os dedicados a Benjamin Constant, localizado na praça da República, no Rio de Janeiro; a Floriano Peixoto, na Cinelândia, também no Rio; e a Júlio de Castilhos, em Porto Alegre, todos obras dos artistas positivistas Eduardo de Sá e Décio Villares. ${ }^{16}$
8. Agulhon, op. cit., p. 142143. O autor retoma essa reflexão em Agulhon (1998, p. 11).

9. Marins (1999, p. 10).

10. Esse aspecto pode ser explicado, em primeiro lugar, pela carência de instituições voltadas à formação local dos escultores até fins do século XIX - exceção feita à Academia Imperial de Belas Artes, no Rio de Janeiro, e à Real Academia de San Carlos de Nueva España, na Cidade do México, instalada em 1785. Cf. Pevsner (1940/2005, p. 194); Pachas Maceda (2007, p. 41-44). Em segundo lugar, pela carência de oficinas de fundição artística, que viabilizassem a realização das obras em metal. Em razão disso, os principais projetos do período foram encomendados a artistas e a oficinas de fundição no exterior. A respeito da fundição artística no Brasil durante o segundo reinado, Cf. Chillón (2018).

11. Cf. Vifian (2014).

12. Cf. Gutiérrez Viñuales (2004, p. 269).

13. Cf. Ribeiro (1999); Knauss (2010).

14. Cf. Vanegas Carrasco, op. cit., p. 30 .

15. Como frisou Michelli Monteiro, em seu estudo sobre o Monumento à Independência em São Paulo, entregar a execução dessas obras a artistas estrangeiros podia significar maior visibilidade internacional para os projetos e a cidade. Cf. Monteiro (2017, 2019).

16. Carvalho (2017, p. 47). 
17. Knauss (2009, p. 390).

18. A estátua de Floriano em Curitiba foi encomendada pela Associação Cívica Floriano Peixoto, cabendo sua execução, após a realização de um concurso, ao escultor de origem italiana Pasquale de Chirico (18731943) e à Artística Fundição de São Paulo, sendo inaugurada em 1904. Cf. Diário da Tarde (1904, p. 1). Por sua vez, em Maceió, a estátua de Floriano Peixoto coube ao escultor também de origem italiana Lorenzo Petrucci (1868-1928), fundida em 1907. Cf. O Malho (1907, p. 24).

19. Para um inventário dos monumentos cariocas, Cf. Dias; Buenos; Acioli (2015). Os anos que se seguiram à proclamação da República foram marcados por uma expansão escultórica no Rio de Janeiro, na qual teve protagonismo o escultor e diretor da Escola Nacional de Belas Artes, Rodolfo Bernardelli (1852-1931), responsável pelos monumentos a General Osório (1894), a José de Alencar (1897), a Duque de Caxias (1899), ao Descobrimento do Brasil (1900), ao jurista Teixeira de Freitas (1905), ao Barão de Mauá (1910) e ao prefeito Pereira Passos (1914).
Desse modo, vemos como houve, sim, uma multiplicação de obras escultóricas pelas cidades brasileiras, apesar de não vivermos aqui uma "febre" monumental semelhante à França da Terceira República. Nesse processo, confrontaram-se versões diferentes sobre o processo da Proclamação da República e visões conflitantes sobre que contornos deveria ter o novo regime, em meio às disputas entre positivistas, jacobinos e liberais, para retomar a formulação de Carvalho.

A disputa pela narrativa histórica do advento do regime republicano e pela definição de quais personagens o protagonizaram ensejou o esforço de produção de imagens e símbolos, como os monumentos positivistas. Por sua vez, Paulo Knauss, observando os diferentes personagens homenageados em pedra e bronze na capital naquele período, concluiu que a "ritualização que envolvia e promovia a escultura pública servia para exibir a diversidade de linhagens políticas que marcavam a sociedade nacional". ${ }^{17}$

Como pontua Carvalho, lembrando do monumento a Júlio de Castilhos em Porto Alegre, não só o Rio de Janeiro vivenciou esse processo. Os novos heróis republicanos, como o marechal Floriano Peixoto, foram monumentalizados em cidades como Curitiba e Maceió iá na primeira década do século XX. ${ }^{18}$ Entretanto, por sua condição de capital do Império e depois do novo regime, foi de fato o Rio de Janeiro o espaço privilegiado para essas homenagens escultóricas, sendo ali que igualmente ergueram-se as vozes mais sonoras na denúncia e rechaço da estatuomania brasileira. ${ }^{19}$ Por esse motivo, nos centraremos nos artigos publicados nos diários cariocas, sem desconsiderar, no entanto, a recorrência contemporânea de textos críticos à estatuomania em jornais de outras cidades brasileiras, revelando sua rápida circulação pelo território nacional.

Para o surgimento da ideia de estatuomania nos jornais brasileiros foi decisiva a mediação cultural promovida por intelectuais que atuavam como colaboradores desses diários, lendo e comentando autores estrangeiros - como o inglês Thomas Carlyle - ou na qualidade de correspondentes na Europa, resenhando o que era publicado na imprensa europeia. Nesse sentido, nos é bastante útil a categoria de intelectual mediador, tal como formulada por Ângela de Castro Gomes e Patrícia Hansen na introdução da obra com título homônimo. O trabalho do intelectual mediador, para as autoras, não se resume a uma passiva transmissão de ideias de um local a outro, pois toda mediação implica uma operação ativa e criadora: 
É fácil perceber como a figura do intelectual mediador - pois é assim que escolhemos nomeá-lo em geral, para abarcar as demais designações - pode ser entendida como a de um mero transmissor. Quer dizer, como a de alguém que conduz uma mensagem ou produto cultural de um lugar a outro, de um tempo para outro, de um código cultural para outro, sem nada acrescentar ou transformar criativamente. Esse sujeito, no mais das vezes, costuma ser visło como alguém que não agrega valor ao produto cultural em questão. Mais ainda, é percebido como tendo "apenas" o papel de "simplificar" ou "didatizar" algum conteúdo, informação etc. [...]. Trata-se de enfrentar um quase paradoxo. Se os estudos de história cultural defendem que todos os sujeitos históricos são produtores de sentidos de forma lata (não há receptor/consumidor/leitor/espectador que seja passivo), e havendo, é certo, aqueles identificados como intelectuais criadores de bens culturais, por que os mediadores não estariam incluídos nessa mesma dinâmica de produção de sentido e de valor?20

Nesse sentido, as autoras sublinham a importância de romper a dicotomia rígida entre "produtores" e "mediadores" culturais. Olhar para o papel do intelectual mediador, como um correspondente de um jornal carioca na Europa, não é apenas identificar os caminhos pelos quais uma ideia penetrou em um novo meio, mas uma dimensão fundamental para compreender seus mutantes significados e os novos usos que assume. Isso porque o intelectual mediador que põe uma "mensagem ou produto cultural" em movimento precisa, ele próprio, se apropriar de "textos, ideias, saberes e conhecimentos", de modo que "aquilo que o intelectual 'mediou' torna-se, efetivamente, 'outro produto'". ${ }^{21}$ Sobre as dinâmicas de apropriação e produção de sentido, diz Roger Chartier:

A apropriação, a nosso ver, visa uma história social dos usos e das interpretações, referidas a suas determinações fundamentais e inscritas nas práticas específicas que as produzem. Assim, voltar a atenção para as condições e os processos que, muito concretamente, sustentam as operações de produção do sentido (na relação de leitura, mas em tantos outros também) é reconhecer, contra a antiga história intelectual, que nem as inteligências nem as ideias são desencarnadas, e, contra os pensamentos do universal, que as categorias dadas como invariantes, sejam elas filosóficas ou fenomenológicas, devem ser construídas na descontinuidade das trajetórias históricas. ${ }^{22}$

Desse modo, sublinhamos que, tal como o conceito de estatuomania, não existem ideias desencarnadas que viajam sozinhas, independentes da atuação dos sujeitos. Não podemos, portanto, estudá-las por si, como se quem as enunciou estivesse apartado do mundo social. Assim sendo, procuramos identificar e analisar quem foram os autores dos textos e imagens discutidos neste artigo, mapeando seus itinerários e engajamentos e reconstituindo as redes de sociabilidade em que se inseriram, ${ }^{23}$ sempre que possível - diante da recorrência de textos anônimos,
20. Gomes; Hansen (2016, p. 16-17).

21. Ibid., p. 18.

22. Chartier (1991, p. 180).

23. Retomamos aqui as coordenadas propostas por Sirinelli (2003, p. 231-269) para a história dos intelectuais. 
24. Gomes e Hansen, op. cit., p. 21.

25. Por exemplo, Cf. Jornal do Commercio (1885, p. 1).

26. Sobre o papel da rede telegráfica e da agência $\mathrm{Ha}$ vas no circuito noticioso carioca-matizando, porém, a ideia de que houve um monopólio da agência francesa -, Cf. Matheus (2012, p. 272-290).

27. Santa-Anna Nery (1899).

28. Rolland (2008). assinados com pseudônimos ou apenas iniciais ou ainda por autores sobre os quais não localizamos dados biográficos.

Entre as modalidades de mediação assinaladas por Gomes e Hansen, está a atuação do intelectual que escreve nos jornais, falando para um público-leitor mais heterogêneo e vasto, como será o nosso caso. ${ }^{24}$ Dessa maneira, cumpre considerarmos como se operou a ponte jornalística entre o Brasil e a Europa, campo de atuação dos intelectuais mediadores aqui abordados. Em muitos dos periódicos brasileiros de maior circulação ao fim do século XIX, havia uma seção intitulada "Telegramas" que, viabilizada pela difusão do telégrafo, facilitou a divulgação de notícias de diferentes lugares do mundo. No Jornal do Commercio, a seção "Telegramas" 25 ocupava a primeira página, em parceria com o Serviço da Agência Havas, trazendo notícias de cidades como Paris, Marselha e Londres. ${ }^{26}$ Para além dos telegramas, que se prestavam a notícias pontuais e a comentar a movimentação marítima e comercial, devido à limitação de caracteres, muitas colunas dos jornais eram escritas por colaboradores correspondentes na Europa, que comentavam as principais notícias do momento nos jornais europeus, desempenhando uma verdadeira mediação cultural transatlântica. Entre eles, podemos citar Frederico de Santa-Anna Nery, que além de escrever para o Jornal do Commercio, colaborou em diversos jornais franceses, sendo autor de obras que visaram divulgar o Brasil e especialmente a Amazônia na Europa, como Le pays des Amazones. ${ }^{27}$

Abordar o tema das reações à estatuomania na imprensa carioca também nos convida a refletir sobre as relações centro-periferia na produção e circulação de ideias e de saberes. Como frisa Denis Rolland, a França foi percebida, pelas elites latino-americanas, como um modelo de civilização no final do século XIX. ${ }^{28}$ A França, em especial sua capital, foi o epicentro de um movimento de proliferação da escultura pública, que depois atingiu outros países europeus e a América, potencializado pela própria ałuação de escultores e oficinas de fundição francesas, como a Val d'Osne, a Barbedienne e a Thiébaut Frères. Porém, dali também partiram as mais fortes críticas a essa aceleração comemorativa, forjando-se a ideia de statuomanie, que, igualmente, ganhou adeptos em outros países.

Não é nossa intenção, a partir dessas reflexões, propor que os intelectuais e periódicos brasileiros simplesmente sofriam influência do modelo francês em suas críticas, transplantando para cá um referencial analítico estranho de forma artificial. Nesse sentido, entendemos como válida a reflexão desenvolvida pela historiadora estadunidense Barbara Weinstein, ao examinar os pressupostos que balizaram a obra Close encounters of empire (publicada em 1998). A despeito de sua reflexão se voltar às relações interamericanas, podemos mobilizar a análise de Weinstein para pensar também a interação entre a América Latina e a Europa. 
Ainda mais, esses historiadores, embora bastante preocupados com o peso do "conhecimento" na questão do poder, geralmente rejeitam o modelo de difusão/disseminação que identifica um único ponto de origem de uma ideia (política, científica, tecnológica, econômical e indica um processo de irradiação desse ponto de origem, de onde ela começa a penetrar novas zonas por vários meios. Em vez desse conceito, que corresponde às noções mais convencionais do "imperialismo cultural", eles preferem o conceito ou a imagem de "circulação cultural" e frisam a constante reformulação de ideias, de propostas e de práticas culturais de um contexto para outro. Então, o exato ponto de origem de certo conceito ou prática (às vezes irrecuperável) é menos importante do que os contextos da sua circulação, implementação e apropriação. ${ }^{29}$

Nesse sentido, a autora propõe ser mais interessante refletir sobre as dinâmicas de circulação e apropriação das ideias. Ademais, é preciso ponderar que uma ideia ou produto cultural só adquire centralidade se consegue mobilizar interlocutores que dela se apropriam em diferentes locais. Assim, Ricardo Salvatore - um dos organizadores da obra de que parte a reflexão de Weinstein - analisou os diálogos entre Leo Rowe, diretor da União Panamericana entre 1920 e 1946, e a intelligentsia argentina, buscando pelas ressonâncias da sua proposta de "cooperação intelectual" nos marcos do ideário pan-americanista. ${ }^{30}$ Salvatore argumenta que o trabalho hegemônico de um império é usualmente mediado por intelectuais locais, especialmente aqueles que ocupam posições em instituições educativas, judiciais, administrativas e culturais, onde certamente poderíamos incluir os postos na imprensa de grande circulação. Dessa forma, esses intelectuais locais traduzem essas ideias, tanto em sentido figurado como literal da palavra - a exemplo do termo "estatuomania" - traçando linhas interpretativas adaptadas às questões e necessidades locais, apresentando-as para seus pares intelectuais e para o público mais amplo. Podemos dizer que o conceito de statuomanie só adquiriu tamanha relevância graças às múltiplas leituras e apropriações que engendrou nas mais diferentes latitudes, assim como o panamericanismo analisado por Salvatore não precisou apenas da atuação dos Estados Unidos para se difundir, mas sim "dependía de la interpretación de múltiples agentes locales, involucrados ellos mismos en la construcción de ideas y políticas acerca de las relaciones hemisféricas". ${ }^{31}$

recorte cronológico delimitado para este artigo se estende entre as décadas de 1880 - quando localizamos os primeiros artigos publicados no Brasil que mobilizam o conceito de estatuomania - e 1930, compreendendo, assim, dois períodos decisivos para a expansão da escultura pública no país: a transição para o regime republicano e a comemoração do primeiro Centenário da Independência, em 1922. É nesse período que o termo estatuomania aparece com maior frequência
29. Weinstein (2013, p. 17, grifo nosso).

30. Salvatore (2007).

31. Ibid., p. 329. 
32. Os jornais e revistas mobilizados neste artigo foram consultados por meio da Hemeroteca Digital da Biblioteca Nacional (BNDigital), no caso dos periódicos brasileiros; da Gallica (Bibliothèque Nationale de France - BnF), no caso dos periódicos franceses; da Hemeroteca Digital da Biblioteca Nacional de España (BNE), no caso dos periódicos espanhóis e argentino; e da Hemeroteca Nacional Digital de México (HNDM), no caso dos periódicos mexicanos.

33. Velloso (2006).

34. Agulhon, op. cit., 1988, p. 138.

35. Larousse (1890, p. 18731874 , grifo nosso). (No original: "STATUEs. f. Encycl. Principales statues inaugurées en France depuis 1871. un grand nombre de statues ont été élevées sur notre territoire depuis 1871. Ces bommages rendus à nos illustrations étaient légitimes au lendemain des désastres que la France a éprouvés. Il est bon, en effet, de mettre sous les yeux d'un peuple malbeureux, mais vigoureux encore, ce qu'ont été ses ancêtres. Il puise dans ce spectacle une consolation en même temps que le désir de se relever en égalant ceux qui l'ont précédé. Mais il fallait éviter les exagérations d'un chauvinisme étroit, et c'est à quoi on n'a pas assez pris garde en célébrant plus d'une médiocrité qu'on eût mieux fait de laisser dans l'ombre. On a ainsi justifié, jusqu'à un certain point, le reproche de statuomanie adressé à notre époque. Nous ne donnerons donc ci-dessous que la liste des statues des vrais grands hommes inaugurées en France depuis 1871"). na imprensa da capital, referindo-se à multiplicação de estátuas ou criticando algum projeto escultórico em especial.

Como fontes documentais para as análises que empreenderemos, apoiamonos em jornais cariocas de grande circulação no período (como o Jornal do Commercio e a Gazeta de Notícias) e em revistas semanais ilustradas (por exemplo, a Fon-Fon! e a D. Quixote), nas quais localizamos as fontes visuais aqui analisadas, além de jornais e revistas estrangeiros (como Le Figaro, La Epoca, Caras y Caretas e El Partido Libera). ${ }^{32}$ Mônica Velloso considera o contexto da Primeira República (1 889-1930), abarcado pelo recorte cronológico aqui adotado, como decisivo na história da imprensa brasileira, quando "se inicia, mesmo em bases precárias, o processo da moderna comunicação de massa e formação de uma opinião pública" ${ }^{33}$ Por fim, para além das fontes visuais analisadas, apresentamos também fotografias de alguns dos monumentos discutidos, para que o leitor possa compreender as polêmicas que os cercaram, extraídas do álbum fotográfico Photographias D. Federal (1911-1920).

\section{STATUOMANIE, ESTATUOMANIA, ESTATUOMANÍA}

Conforme pondera Maurice Agulhon, ${ }^{34}$ o conceito de statuomanie apareceu no segundo suplemento do dicionário de Pierre Larousse, Grand Dictionnaire Universel du XIXe Siècle, no tomo XVII, de 1880-1890. Na verdade, não há no dicionário um verbete específico com esse nome, apenas uma reflexão desenvolvida dentro do verbete "Estátua", que apresenta o termo e o explica, antes de listar os monumentos inaugurados na França desde o início da Terceira República:

ESTÁTUA s. f. Encycl. Principais estátuas inauguradas na França desde 1871. Um grande número de estátuas tem sido erguido em nosso território desde 1871 . Essas homenagens às nossas ilustrações foram legítimas após os desastres que a França experimentou. É bom colocar diante dos olhos de um povo infeliz, mas ainda vigoroso, o que foram seus ancestrais. Desse espetáculo ele tira um consolo, ao mesmo tempo que o desejo de se erguer, igualando-se aos que o precederam. Mas era preciso evitar os exageros de um estreito chauvinismo, e é a isso que não temos prestado atenção, celebrando mais de uma mediocridade que seria melhor deixar na sombra. Assim, justificou-se, até certo ponto, a censura à statuomanie dirigida à nossa época. Por isso, apenas daremos a seguir a lista das estátuas dos verdadeiros grandes homens, inauguradas na França desde 1871.35 
Contudo, Agulhon também apresenta manifestações que, desde a primeira metade do século XIX, condenavam a "mania das estátuas", a exemplo de um artigo publicado no Journal de Viennet em julho de 1842. ${ }^{36}$ Destacou-se, já na centúria seguinte, o livro de Gustave Pessard, Statuomanie parisienne: étude critique sur l'abus des statues, publicado em 191 1,37 que gozou de prestígio à época, rastreável pela sua aquisição por bibliotecas municipais parisienses ${ }^{38}$ e pelas numerosas resenhas que recebeu na imprensa contemporânea. ${ }^{39}$ Antes de aparecer no dicionário de Larousse e de ser o título do livro de Pessard, porém, o termo batizou um poema de Auguste Barbier, ${ }^{40}$ de 1850, incluído posteriormente na obra Les Satires, em 1865. A statuomanie, expressão do culto aos "grandes homens", é percebida por Barbier como um sinal de decadência logo nos primeiros versos do poema:

Como nos dias de declínio do Império de Roma,

A moda hoje é bancar o grande homem,

De se dar, vivo, os ares de um imortal

E ter como um santo seu nicho e seu altar. ${ }^{41}$

No Brasil, ainda que o Rio de Janeiro concentre o maior volume de artigos publicados sobre a estatuomania na virada dos séculos, não foi em um jornal dessa cidade onde pela primeira vez se publicou um texto sobre o tema. ${ }^{42} \bigcirc$ primeiro artigo que localizamos utilizando o termo traduzido para a língua portuguesa, "estatuomania", é datado de 4 de novembro de 1884, no jornal maranhense Pacotilha, sob o título "De Pariz", sem data nem autoria assinaladas. ${ }^{43} \bigcirc$ mesmo texto, porém, também foi publicado mais de vinte dias depois, em 26 de novembro, no jornal Cearense, de Fortaleza, trazendo a informação "Paris, outubro de 1884". Diz o autor desconhecido, em tom de denúncia:

A estatuomania e o cólera vão grassando pela França. Em poucos meses erigiram-se mais estátuas do que em muitos anos. Viva a nova epidemia, (não o cólera) que glorifica o talento das ilustrações do Século das luzes, às vezes apagadas. Depois da estátua de Dumas, a ostentar-se ufana em Paris, a cidade de Châtres tem hoje a honra de possuir uma da grandiosa George de Sand. Muitos vultos científicos vão passando à posteridade, em bronze e mármore, bem como alguns marrecos de incontestável mediocridade, protegidos até na morte, pelos saltimbancos políticos. Aquilatando o mérito dos personagens, cujas efigies ornam ou desornam as praças públicas, o povo, grato e sensato, sabe render homenagem a umas, voltando às outras a parte em que as costas mudam de nome. ${ }^{44}$
36. Reproduzimos aqui a citação de Agulhon: "A mania das estátuas se propaga como uma epidemia. Cada cidade quer ter a sua. Méhul acaba de ser plantado como uma quilha em uma praça de Givet. Prepara-se a de Jouffroy em Grenoble e a de Caillé não sei onde. Um jovem parte do Senegal, chega a Timbuktu, atravessa o deserto e vai atingir o Marrocos. E é revestido de mármore em um pedestal! Que escárnio...". Extraído de Journal de Viennet, pair de France, témoin de trois règnes, Paris, Amiot-Dumont, 1955, p. 266 Apud Agulhon, op. cit., 1988, p. 109-110. (No original: "La manie des statues se propage comme une épidémie. Chaque ville veut avoir la sienne. Mébut vient d'être plante comme une quille sur une Place de Givet. On prépare celle de Jouffroy à Grenoble et celle de Caillé je ne sais où. Un jeune homme part du Sénégal, arrive à Tombouctou, traverse le désert, va toucher au Maroc. Et on le guinde en marbre sur un piédestal! Quelle dérision...").

37. Pessard (1911)

38. "Artigo primeiro - será adquirido, ao preço de 2 francos cada, 2 exemplares da obra do sr. Pessard, intitulado 'Statuomanie'. Esses exemplares serão atribuídos à biblioteca do Conselho Municipal e à biblioteca administrativa". Paris (1912, p. 496). (No original: " $A r$ ticle premier. - Il sera acquis, au prix de 2 francs l'un, 2 exemplaires de l'ouvrage de M. Pessard, intitulé 'Statuomanie'. Ces exemplaires seront attribués à la bibliothèque du Conseil municipal et à la bibliothèque administrative").

39. Cf. Les Entretiens idéalistes (1911, p. 335-336); L'Intermédiaire des chercheurs et curieux (1911); Brandes (1912, p. 721). 
41. No original: "Comme aux jours déclinants de l'empire de Rome, /La mode est aujourd'bui de jouer au grand homme, /De se donner, vivant, les airs d'un immortel /Et d'avoir comme un saint sa niche et son autel". Barbier (1869, p. 199). A data original de publicação, 1850, consta ao final do poema.

42. Com isso, não pretendemos afirmar que esta foi a primeira utilização da palavra "estatuomania" na língua portuguesa, haja vista que os periódicos portugueses não foram contemplados nesta investigação. No diário português Commercio de Portugal, por exemplo, em 1879, fala-se em "mania das estátuas": "tem-se desenvolvido sensivelmente em França, a mania das estátuas, com a qual nada perdem os escultores. Rabelais vai ser honrado com uma estátua em Chinon. Fala-se também em tributar igual honra a Beranger e Theophilo Ganthier". Commercio de Portugal (1879, p. 2).

43. Pacotilha (1884, p. 2).

44. Cearense (1884, p. 2).

45. Por exemplo, na edição do dia anterior, a seção "Correspondencia pariziense" de Nolasco traz informações sobre as movimentações militares europeias na China e sobre a epidemia de cólera na França. Nolasco (1884, p. 2). Para se ter uma ideia da periodicidade dessa coluna, localizamos sua presença também nos dias 25 de outubro, 14 de outubro, 4 de outubro e 25 de setembro de 1884 , todas assinadas por Nolasco. Porém, nos parece pouco provável que este colaborador tenha escrito um texto sobre as atualidades francesas fora de sua habitual coluna e sem assinatura.
O fragmento acima faz parte de um texto mais longo, que tece comentários gerais sobre os últimos acontecimentos na França, separados por asteriscos, ao estilo das crônicas enviadas pelos correspondentes no exterior. Porém, no diário maranhense Pacotilha não havia uma coluna periódica intitulada "De Pariz", de modo que esse texto não se enquadra em uma série regular dentro do jornal. Por outro lado, havia na folha maranhense uma seção intitulada "Correspondencia pariziense", assinada por "Dr. J. P. Nolasco" desde Paris, que trazia regularmente notícias panorâmicas da França e da Europa. ${ }^{45}$ Desse modo, não podemos atribuir com segurança a autoria desse texto, nem mesmo se foi uma contribuição originalmente destinada ao Pacotilha. Como abordou Letícia Matheus, privilegiando o universo da telegrafia, é preciso considerar a rede de colaboração que operava entre muitos jornais brasileiros na segunda metade do século XIX, por meio da qual textos e notícias eram compartilhados e replicados. ${ }^{46}$ Desse modo, torna-se nebulosa a origem desse artigo.

Por sua vez, a primeira menção à palavra estatuomania localizada na imprensa da então capital brasileira ocorre em 17 de agosto de 1885 no folhetim "Ver, ouvir e contar", do Jornal do Commercio:

Paris, 23 de julho de 1885: Quem foi que por aí começou a queixar-se da estatuomania, desta nova moléstia contemporânea que é caracterizada pelo prurido de povoar as praças de marmóreas estátuas ou de brônzeos monumentos? A estatuomania é sublime enfermidade. Exprobamos outrora a ingratidão dos povos. [...]. A nossa época positiva é mais generosa: repara as ingratidões dos nossos antepassados, e vai erigindo padrões de glória aos antigos e coevos varões assinalados. Este mês de julho vi o triunfo de uma meia-dúzia desses grandes homens. [...]. Os nossos netos não poderão mais dar dois passos sem toparem com alguma estátua. ${ }^{47}$

Apesar desse texto também não estar assinado, é possível resgatar a sua autoria, uma vez que foi publicado em uma coluna fixa do jornal, o que pode trazer contribuições importantes para a reflexão aqui proposta. $\bigcirc$ folhetim "Ver, ouvir e contar", que publicou o excerto, era reproduzido quinzenalmente no rodapé da primeira página do Jornal do Commercio desde $1874,{ }^{48}$ sem receber qualquer assinatura até 1889, sendo escrito em Paris e lançado com um mês de atraso na folha fluminense. Contudo, segundo Nelson Werneck Sodré, que coloca o "Ver, ouvir e contar" entre os mais importantes folhetins da época, a coluna teve como primeiro folhetinista o barão de Santa-Anna Nery. ${ }^{49}$ Frederico de Santa-Anna Nery (1848-1901), nascido em Belém do Pará, iniciou seus estudos em Manaus e foi ainda jovem para a Europa, diplomando-se em Letras 
em Paris (1867) e fixando residência na capital francesa em 1874, mesmo ano de estreia do folhetim, depois de uma passagem por Roma. ${ }^{50}$

pesquisador João Carneiro argumenta que os posicionamentos políticos de Santa-Anna Nery, marcados pela proximidade com a Santa Sé e por seu apoio à monarquia e ao Imperador, contribuíram para o seu posterior apagamento pela historiografia republicana. ${ }^{51}$ Contudo, antes mesmo da Proclamação da República, pondera o autor, seus posicionamentos e sua produção intelectual eram ironizados na imprensa carioca, a exemplo da Revista Illustrada, em que se publicavam críticas que desprestigiavam o folhetinista e seu folhetim, acusando-o de simplesmente traduzir os artigos da imprensa francesa, especialmente do jornal Le Figaro. Segundo o articulista André Gil, o título do folhetim deveria ser "Escolher, traduzir e mandar".

Pudesse eu seguir a mesma estratégia de ir-me inspirar na Europa, e veriam que boas Crônicas, havia de dar aos leitores da Revista. Estabelecia logo concorrência com o folhetinista do Jornal... Era Figaro quá Figaro lá, tesourada dali tesourada de cá, e estava alinhavada a Crônica... [...]. Somente haveria de escolher um título mais análogo ao programa e em vez de ver, ouvir e contar, escrevia mais escrupulosamente escolher, traduzir e mandar. ${ }^{52}$

No mesmo sentido, em outro texto da revista, publicado em 1879, o articulista identificado como Junio acusa o folhetinista de "Ver, ouvir e contar" de apenas ler o jornal Le Figaro e dele "nos dar uma segunda edição incorreta". 53 Junio vai além e critica os posicionamentos políticos de Santa-Anna Nery, acusando-o de preferir um Napoleão IV no trono do que a Terceira República francesa, "intrigando Gambetta com o papá [sic] Leonardo" - referência a Leão XIII, papa entre 1878 e 1903. A despeito do nítido e debochado desprezo pelo escritor paraense - "é bastante tolo para a gente rir-se apenas" - esses textos revelam o perfil conservador de Santa-Anna Nery, suas simpatias clericais e monárquicas, vinculando-se a grupos que, como já argumentou Maurice Agulhon, foram bastante críticos à proliferação da escultura pública na França. Por outro lado, fica patente que Santa-Anna Nery era um leitor do conservador jornal francês Le Figaro, ${ }^{54}$ em cujas páginas foram publicadas constantes críticas à statuomanie desde 1868. ${ }^{55}$ Assim fica expresso no apelo de Charles Chincholle, quando da inauguração de uma estátua a Louis Blanc em Paris em comemoração ao aniversário da Segunda República: "Definitivamente, é hora de acabar com a statuomanie. Pedimos humildemente sr. [Jean-Charles] Alphand, que zela com um cuidado tão ciumento pela beleza de sua Paris, que tire dela tudo o que, sob a pretensão da arte, a desonra verdadeiramente". ${ }^{56}$
46. Matheus, op. cit.

47. Jornal do Commercio (1885, p. 1, grifos nossos).

48. A primeira publicação que pudemos localizar desse folhetim data de novembro deste ano: Jornal do Commercio (1874, p. 3).

49. Sodré (1999, p. 292).

50. Nossa referência para a trajetória de Santa-Anna Nery é a tese de Carneiro (2013).

51. Carneiro, op. cit.

52. Gil (1877, p. 2). Devo à pesquisa de João Paulo Carneiro as referências que me levaram aos artigos da $R e$ vista Illustrada.

53. Junio (1879, p. 7).

54. De fato, ainda que de passagem, Santa-Anna Nery menciona o Le Figaro já na primeira publicação do folhetim "Ver, ouvir e contar", em novembro de 1874 .

55. O primeiro texto crítico à statuomanie que pudemos localizar no Le Figaro é datado de maio de 1868 , mas não aborda a França, e sim a Itália. Le Figaro (1868, p. 2).

56. Chincholle (1887, p. 2 , grifo nosso). No original: "Décidément il est temps d'en finir avec la statuomanie. Nous prions bumblement M. Alphand, qui veille avec un soin si jaloux sur la beauté de son Paris, d'en ôter tout ce qui, sous la prétention d'art, le déshonore vraiment". 
57. Jayme de Séguier (18601932) foi bastante reconhecido por seu Dicionário Práctico da Língua Portuguesa, publicado em 1910 , e que recebeu numerosas reedições. Séguier atuou, segundo notas publicadas no Jornal do Commercio, como cônsul português na cidade francesa de Bourdeaux. Jornal do Commercio $(1883$, p. 1). O escritor, apesar de colaborar com a folha fluminense à distância, viajou ao Brasil e pôde conhecer a redação do Jornal do Commercio em 1890. Segundo o folhetim "O que vai por aî", escrito em Lisboa em 12 de agosto de 1890, Séguier embarcou com destino a Buenos Aires, com a finalidade de negociar a exportação dos vinhos portugueses na região rio-platense, fazendo uma escala no Rio de Janeiro. Na ocasião, descrito como "emérito colaborador desta folha e jornalista de além-mar Jayme de Séguier", foi recepcionado com um "delicado almoço, no salão superior do Globo". Jornal do Commercio (1890, p. 1) e Jornal do Commercio (1890, p. 1).

58. Séguier substituiu Santa-Anna Nery na redação do folhetim entre 1887 e 1888. Isso porque o primeiro texto que recebeu assinatura na coluna foi publicado em fevereiro de 1890 , firmado pelo pseudônimo "Iriel", que, na ocasião, anunciou já escrever aquele folhetim há três anos, sem o direito ao sacramento do batismo, isto é, dar a conhecer o seu nome. Iriel (1890, p. 1). Conforme Simões Júnior (2019, p. 20), Jayme de Séguier assinou, no folhetim, os pseudônimos de Iriel e Alter Ego, além de utilizar o próprio nome. Por outro lado, segundo Carneiro, o próprio Santa-Anna Nery escreveu, em um livro autobiográfico, publicado em 1898, que contribuiu para o
Considerando esses aspectos, é evidente a importância de investigar quem são os atores que promovem a mediação e a circulação dessas ideias, suas trajetórias e seus posicionamentos na arena políitico-ideológica.

Ao lado de Santa-Anna Nery, trabalhando como colaborador e correspondente do Jornal do Commercio na França, esteve o português Jayme de Séguier. ${ }^{57}$ Conforme Werneck Sodré e Carneiro, Séguier substituiu o escritor paraense na redação do folhetim "Ver, ouvir e contar" que, a despeito da mudança de autor, não mudou de nome. ${ }^{58}$ Por sua vez, a estatuomania continuou sendo um tema recorrente nessa coluna. Em 1896, Séguier denunciou:

\begin{abstract}
A estatuomania continua a grassar com intensidade. Desde a minha última crônica brotaram do solo, com o obrigado acompanhamento do discurso oficial, um novo bronze lo vigésimo, a menos que não seja o quinquagésimol de Carnot, em Châlons sur Marne; um monumento a Doudart em Lagrée, o primeiro explorador do Mékory; a estátua do general Barbanègre, um dos Aquiles da llíada napoleônica. E começa a falar-se na estátua de Sainte-Beuve, assim como na de Charles de Bernard. ${ }^{59}$
\end{abstract}

Nesse período, o termo estatuomania já aparecera nos jornais de diferentes cidades brasileiras, evidenciando a sua rápida circulação. Em dezembro de 1885, surge nas páginas do Diario do Gram-Pará, em Belém, quando se comenta sobre a ereção de novas estátuas na França: "Balzac, o célebre autor da Comédia humana, vai ter duas estátuas, uma em Paris e a outra em Tours. Estamos na época da estatuomania". 60 Por sua vez, o jornal ouro-pretano Minas Geraes, em 1899, reproduziu um texto do Le Figaro, em que o periódico rebate a acusação de que a statuomanie seria um "problema" exclusivamente francês, lembrando os numerosos monumentos a Bismarck e ao imperador Guilherme na Alemanha. Conclui o jornal mineiro: "afinal de contas, a estatuomania é uma doença exclusiva da França? É a interrogação que a réplica de Figaro sugere". 61

Ao mesmo tempo que no Brasil aparece o termo estatuomania, nos jornais de língua espanhola surge a palavra "estatuomanía", como publicado no diário madrileno La Epoca, em 1881:

La estatuomanía va tomando proporcionas alarmantes y ridículas en Francia. En Águila [L'Aigle] se pensaba no ha mucho erigir una estatua, ¿̇à quién dirán Ustedes? al historiador romano Salustio, que murió, como es sabido, hace unos dos mil años. ${ }^{62}$ 
Como indica a publicação, as primeiras aparições de estatuomanía na imprensa espanhola fizeram referência ao universo francês. ${ }^{63}$ Posteriormente, o conceito foi empregado pelos articulistas para se referir à realidade espanhola por diferentes pontos de vista, seja para lamentar a ausência de um fenômeno parecido no reino, 64 seja para alertar que essa "enfermidade" já se avizinhava. ${ }^{65}$

Cruzando o oceano Atlântico, encontramos as primeiras ocorrências do termo traduzido para o espanhol nos jornais do México, desde a década de 1890, ${ }^{66}$ mais uma vez, se manifestando a princípio em relação à França e, depois, sobre o contexto mexicano. ${ }^{67}$ Em 1892, foi publicado um artigo no jornal El Partido Liberal sob o título "Un busto del doctor Guillotin". No texto, o articulista protesta contra a decisão do diretor de Belas Artes francês de encomendar um busto do dr. Guillotin - cujo nome batiza a guilhotina - para o salão do Jeu de Paume do Palácio de Versalhes, "entre tantos hombres célebres, que a pesar de la estatuomanía reinante, no tienen todavía su efigie en bronce o en mármol" .68 Como revela a advertência abaixo do título, "traducido para El Partido Liberal", tratava-se de um artigo originalmente publicado em um diário estrangeiro e traduzido para a língua espanhola.

De fato, um texto de conteúdo idêntico já havia saído antes na França, no jornal Le Temps, em 17 de julho de 1892. Para a tradução do texto original em francês, no qual consta o termo statuomanie, elegeu-se, portanto, a palavra estatuomanía. ${ }^{69}$ Anos depois, em fevereiro de 1895, foi publicado um artigo no diário El Siglo Diez y Nueve no qual o articulista, para além de apenas traduzir um texto em francês, acrescentou um comentário pessoal, mobilizando ele próprio o conceito de estatuomanía e interpretando-o como uma extensão do que considera a enfermidade francesa: "no ignora el lector que de veinte años acá la estatuomanía que de una forma irresistible de la vanidad, viene haciendo verdaderos estragos entre los franceses, que como vanidosos lo son hasta el punto de que es lícito afirmar que la vanidad es una enfermedad francesa" ${ }^{70}$

Em dezembro de 1898, porém, a palavra estatuomanía apareceu, sem qualquer menção à França, no discurso do jornalista mexicano Francisco Sosa, pronunciado em um sarau literário no Teatro Llave, na cidade de Orizaba, estado de Veracruz, quando se inaugurava ali a estátua do sacerdote José Nicolás del Llano. Diferente dos críticos, Sosa - que anos antes havia lançado uma proposta de instalação de estátuas no Paseo de la Reforma da capital mexicana ${ }^{71}$ - rechaça - rótulo de estatuomanía e defende a escultura pública como uma legítima demonstração de gratidão. Para ele, os detratores das esculturas eram apenas invejosos inimigos da glória alheia: folhetim por quatorze anos, isto é, entre 1874 e 1888 , seguindo, porém, como "correspondente político" do Jornal do Commercio na França após essa data. Carneiro, op. cit., p. 109.

59. Séguier (1896, p. 1, grifo nosso).

60. Diario do Gram-Pará (1885, p. 2).

61. Minas Geraes (1899, p. 4).

62. La Epoca (1881, p. 2, grifo nosso).

63. Poucos dias após essa nota, na seção "Cartas Parisienses" do mesmo jornal, assinada por Mascarille, foi publicado: "La manía de la república actual es la estatuomanía. Sobra el mármol pero faltan los grandes hombres". Mascarille (1881, p. 4).

64. Para o jornalista aragonês Mariano de Cávia (1903, p. 1), pior do que a estatuomanía era a mania do esquecimento: "En propio honor de los pueblos que saben honrar la memoria de sus bijos redundan a la postre esos homenajes que en naciones más dadas que la nuestra al culto del indigena se han calificado de 'estatuomanía'. Dígase cuanto se quiera contra el uso y abuso del pedrusco bonorífico y del bronce conmemorativo, en semejante manía quisiera yo que cayesen nuestras ciudades, villas y lugares, tan propensos a la manía contraria: a la de hacer polvo sus figuras más gloriosas".

65. La República (1891, p. 2) denunciou: "Hoy celebrará sesión el Ayuntamiento. ¿Y qué dirán ustedes que han proyectado varios concejales? Pues presentar una proposición para que se coloque en una plaza pública la estatua de Jovellanos. Como se 
ve, a varios de los ediles madrileños les ha entrado una enfermedad que pudiera llamarse estatuomania". A nota se encerra defendendo que fossem erigidas estátuas para todos os concejales madrilenos favoráveis a medidas como aquela, a fim de que os eleitores os conhecessem e não os reelegessem.

66. Antes da década de 1890 , em 1882, já havia aparecido o termo statuomanie no jornal Le Trait d'Union (1882, p. 3), comentando a ereção em Paris de uma estátua de bronze a Camille Desmoulins. Sobre esse jornal, publicado no México em língua francesa, Cf. Santiago Gómez (2019).

67. Elegemos mencionar o México aqui, entre os países hispano-americanos, devido ao duplo pioneirismo desse país no âmbito da escultura pública americana. Como já dito, foi ali aberta a primeira academia de arte do continente, na década de 1780. Ainda no período colonial, foi fundida em bronze na capital mexicana a estátua equestre do rei Carlos IV, conhecida como el caballito, obra do valenciano Manuel Tolsá (1757-1816), monumento inaugurado em 1803 e depois transferido para o Paseo de la Reforma. Gutiérrez Viñuales (1997, p. $91 ; 2004$, p. 46); Fernandes (2012, p. 180-181).

68. El Partido Liberal (1892, p. 2). Cabe ponderar que o jornal El Partido Liberal, apesar de veicular esse artigo crítico à estatuomanía, teve, anos antes, um papel decisivo na expansão da escultura pública da capital mexicana. Cf. nota 71 .

69. No original: "Entre tant d'bommes célèbres qui, malgré la régnante statuomanie, n'ont pas encore leur effigie en bronze ou en
El hecho hoy realizado es tanto más meritorio, cuanto que - aunque parezca increíble en las postrimerías del siglo ilustrado en que nos tocó nacer - parece que se conjuran para impedir actos de esa especie, los encarnizados enemigos de toda gloria ajena, los modernos iconoclastas que anhelan arrancar de sus pedestales las estatuas de los hombres superiores; los que por hacer alarde de sabios y de cosmopolitas comparan la grandeza de sus conterráneos con la grandeza de los más ilustres personajes de la antigüedad, para deducir de allí que es irrisorio elevar monumentos a los que no miden la talla de que suponen capaces nada más que a los semidioses de otros pueblos. [...] Esos soberbios, esos envidiosos, esos seres inferiores, son los que en nuestra época hablan de la estatuomanía cuando se verifica una solemnidad como la que hoy regocija a Orizaba. Incapaces para reconocer el mérito ajeno, ocultan tras la careta de su desdén olímpico la pasión que les roe las entrañas. ${ }^{72}$

Dessa forma, fica nítido que o conceito de statuomanie circulou em diferentes línguas, assim como engendrou dinâmicas paralelas de apropriação em contextos distintos, nos discursos de intelectuais que não se limitaram a narrar ou examinar o que acontecia na França, de modo que não reivindicamos para o fenômeno analisado qualquer exclusividade local. Esse movimento também teve lugar nas páginas dos diários cariocas, nos quais a palavra estatuomania passa paulatinamente a ser mobilizada para se referir à própria realidade da cidade.

\section{UMA MANIA NOS DOIS LADOS DO ATLÂNTICO}

Após as primeiras publicações, o termo estatuomania se tornaria recorrente nas páginas dos jornais cariocas, em artigos em que comumente se interpretava o fenômeno como uma doença que se espalhava como uma epidemia. Na coluna Omnibus da Gazeta de Notícias, denunciava-se, ao lado da epidemia de estátuas, a de placas:

Ao lado da estatuomania, que grassa em França epidemicamente neste momento, pode pôr-se esta outra - a placomania. Há pouco, na casa n. 9 do Boulevard des Italiens, assentou-se uma placa de mármore, comemorativa do compositor Grétry, que ali morou. E com esta são já seis placas destinadas a músicos, porque existem ou estão para ser postas as seguintes: Victor Massé, aven. Frochot; Auber, r. St. Georges; Rossini, chauss. d'Antin; Herold, r. Hérold; e Berlioz, r. de Calais. ${ }^{73}$

Contudo, nem todos os textos tinham a mesma nota crítica, demonstrando simpatia pela difusão dos monumentos. Escrevendo de Paris, em 25 de junho de 1906, Garcia Redondo 74 dizia que a "França continua com a febre das inaugurações e com a estatuomania", após a inauguração de duas estátuas na véspera. Ao invés de criticar 
a iniciativa, porém, o articulista lamentava não ter acompanhado a solenidade de uma delas, dedicada a Alfred de Musset, indo ao cemitério Père-Lachaise visitar o túmulo do homenageado. No cemitério, sentiu desejo de beijar o busto de Musset, mas foi impedido pela chegada de um grupo inoportuno de visitantes ingleses. ${ }^{75}$

Os primeiros textos publicados na imprensa carioca sobre o tema da estatuomania limitavam-se a comentar a realidade francesa, uma vez que eram frequentemente escritos por colaboradores que lá viviam. Como vimos, os artigos publicados em jornais de outras cidades, como Belém, Fortaleza e São Luís - e em outros países, como na Espanha e no México -, compartilharam a princípio esse caráter. Apenas a partir da década de 1890, após a Proclamação da República, se publicaram textos que buscavam mobilizar o conceito não só para comentar a situação francesa, mas para analisar o cenário urbano carioca. ${ }^{76}$ Mesmo esses artigos, porém, faziam menção à França, geralmente logo na abertura do texto: comentavam a inauguração de uma nova estátua, a publicação de um artigo na imprensa, a indignação que isso causava etc.

Podemos distinguir duas posturas nesse universo de textos que ensaiavam análises sobre a estatuomania brasileira que, de modo geral, se sucedem. Entre fins do século XIX e os primeiros anos do século XX, predominam os discursos que consideravam a estatuomania um problema instalado na urbe. Em 1901, no jornal A Notícia, o articulista L. Flaminio assim comentou a proposta da Academia Brasileira de Letras para que se respeitasse um período mínimo antes de se construir uma homenagem escultórica:

Bem andou a Academia de Letras, lembrando-se de pedir ao conselho municipal a decretação de uma lei que marque um prazo post-mortem para a colocação de estátuas e bustos nos jardins da cidade. Nós, brasileiros, temos o entusiasmo fácil, e por isso mesmo, pouco duradouro. Deixamo-nos inflamar de admiração com uma presteza extraordinária, e com a mesma presteza, não raro, passamos em breve tempo a apedrejar aquilo que aplaudimos. Não há como o tempo para colocar homens e coisas no lugar que verdadeiramente thes compete, dando-thes o justo valor, e corrigindo as deficiências ou os exageros da crítica dos contemporâneos. [...] A estatuomania, é justo dizê-lo, não é uma moléstia somente nossa. Também a Europa está sofrendo dessa singular doença. A menor cidade, a mais pobre aldeia, o mais pobre burgo, querem ter um grande homem seu, perpetuado em pedra e bronze. ${ }^{77}$

Do mesmo modo, em 1906, em artigo publicado na revista Leitura para todos, Jayme de Távora interpretou a estatuomania como um mal já vigente na capital: "O Rio de Janeiro, cidade que sempre imita as manias das outras, não podia ficar imune. Também a nossa capital sofre da estatuomania".$^{78}$

Contudo, tornam-se mais frequentes discursos que reconheciam ainda não haver uma estatuomania no Rio de Janeiro semelhante à parisiense, ainda que marbre, pourquoi le docteur Guillotin est-il choisi? On l'ignore". Le Temps (1892, p. 1).

70. $\mathrm{O}$ articulista prossegue, argumentando que, nesse "furor de glória póstuma", levantam-se na França muitas estátuas a personagens anônimos, enquanto alguns de merecida homenagem eram esquecidos. Por fim, para exemplificar esse argumento, transcreve a tradução de um artigo publicado na França sob o título "Dos franceses sin estatua", no qual ironiza como as pessoas do futuro (precisamente, do ano 2.194), após realizarem escavações arqueológicas no território antes habitado pelos franceses - povo atacado de uma "locura colectiva especial: la estatuitis aguda" -, estranhariam a ausência de estátuas dedicadas Musset e Balzac. El Siglo Diez y Nueve (1895, p. 2).

71. Francisco Sosa (18481925) foi um jornalista, historiador e biógrafo mexicano. Ocupou postos de relevo, como o de membro da Real Academia Española de la Lengua, deputado no Congreso de la Unión e diretor da Biblioteca Nacional. Cf. Carreté (1986, p. 2122). $\mathrm{Na}$ introdução que escreveu para a segunda edição de sua obra, Las estatuas de la Reforma, publicada em 1900, Sosa assim descreveu seu papel na elaboração do projeto que resultou na construção de estátuas no Paseo de la Reforma da capital mexicana: "Mediaba el año de 1887 cuando el periódico intitulado El Partido Liberal se dignó dar bospitalidad a un artículo escrito por el autor de este libro, con el fin de proponer a la prensa nacional que tomase bajo su patrocinio una idea concebida al calor del entusiasmo por las glorias patrias, $y$ enderezada a fomentar el arte nacional y a procurar que en la primera ciudad 
de la República se encuentren siempre representadas bonrosamente todas y cada una de las entidades federativas". Sosa (1900, p. VIII-IX). Nesse artigo, publicado no jornal El Partido Liberal em 1887, Sosa propôs que cada um dos diferentes Estados mexicanos financiasse a construção de duas estátuas dedicadas a homenagear suas personalidades locais mais salientes, que seriam erigidas sobre pedestais presentes no Paseo de la Reforma da Cidade do México - que já contava então com estátuas de Cristóvão Colombo e Cuauhtémoc. Segundo o relato presente na introdução à segunda edição do livro, de 1900, essa proposta ganhou ressonância na imprensa e foi rapidamente abraçada pelo governo mexicano, que em outubro de 1887 lançou uma circular dirigida aos governadores estaduais, convidando-os a doar as estátuas ao Paseo de la Reforma. Até abril de 1899, mais de três dezenas de estátuas já haviam sido inauguradas no local. Sobre esse tema, Cf. Gutiérrez, op. cit., 2004, p. 68-69.

72. O discurso de Sosa, lido em 4 de dezembro de 1898 , foi reproduzido no jornal $E l$ Nacional, em janeiro do ano seguinte. Sosa (1899, p. 1-4, grifo nosso).

73. Gazeta de Notícias (1894, p. 2).

74. Manuel Garcia Redondo (1854-1916) foi engenheiro e jornalista, membro da Academia Brasileira de Letras. Ver o site da Academia Brasileira de Letras (sem data).

75. Garcia Redondo (1906, p. 3).

76. O primeiro texto publicado na imprensa carioca a mobilizar o conceito de "estatuomania" para analisar a realidade do Rio de Janeiro buscassem alertar para os riscos desse fenômeno como um problema iminente. Em 1913, o seguinte texto, sem autoria identificada, foi publicado no jornal $O$ Imparcial:

\begin{abstract}
Embora não sejamos dos povos mais atacados pela estatuomania e até primemos pelo descaso em que deixamos os grandes antepassados, que bem mereceram a consagração do bronze e do mármore, sempre é bom estarmos ao corrente do que se faz aí por fora para sustar ou esmorecer essa espécie de homenagens humanas. É possível que um dia adotemos o culto dos homens a ponto de transformá-lo em calamidade, e então já saberemos os meios utilizáveis nessas aflitivas e honrosas circunstâncias. Ainda há poucos dias, bebida em fontes oferecidas pelas folhas francesas, publicamos aqui a estatística, ou antes, o recenseamento das estátuas parisienses, que são, ou eram em número de duzentas e oitenta e cinco. Apavorada com essa população estarrecida no metal e na pedra, recenseada pelos zeladores artísticos da cidade, e com as petições pedindo lugar para mais vinte e oito silenciosas criaturas predecessoras da mulher de Loth, o Conselho Municipal de Paris resolveu tomar uma providência enérgica, tendente a evitar a obstrução das praças e avenidas por essa multidão macambuzia e eterna, que não circula nem paga imposto. E daí as resoluções postas recentemente em vigor. De agora em diante, inabalável no seu propósito, a municipalidade não só não favorecerá mais comitês destinados ao levantamento de estátuas ou monumentos, como não tomará, sequer, conhecimento de maquetes antes que uma comissão especial haja estudado a oportunidade da homenagem [... $]^{79}$
\end{abstract}

No mesmo jornal, após mais de dez anos, em 1924, Pedro Peralta afirmou: "no Rio, elas [estátuas] não constituem, ainda, multidão. As que existem já são bastantes, porém para ridicularizar perante os vivos os mortos heróis que representam" ${ }^{80}$ Nesse mesmo ano, o articulista que assina como "FR" no jornal $O$ Paiz entendeu que esse era um problema que só então começava a se instalar na cidade:

Há anos, em Paris, abriu-se tenaz campanha, entre as pessoas de bom gosto, por ela se havendo interessado o poder público, no sentido de impor-se limites à estatuomania que tendia povoar a cidade de cavalheiros dos mais extravagantes aspectos. Entre nós, ainda não se cogitou daquele problema, que é da maior oportunidade, pois o Rio, agora é que começa a sofrer de tão estranha moléstia. Há, atualmente, vários projetos de monumentos públicos. Concursos se abrem e se encerram, sem que se medite no referido perigo. ${ }^{81}$

Podemos notar uma contradição cronológica nessas manifestações, uma vez que, especialmente com a aproximação do Centenário da Independência, em 1922, mais concursos foram abertos e monumentos inaugurados na cidade ao longo da primeira metade da centúria. Para elucidar essa questão, primeiramente mencionamos a impressão deixada pela inauguração, em um período relativamente curto, dos primeiros monumentos republicanos - ao General Osório (1 894), a José de Alencar 
(1897), ao Duque de Caxias (1 899), ao Descobrimento (1900) e ao Visconde de Rio Branco (1902), entre outros. Essas inaugurações marcaram uma ruptura abrupta com a cidade herdada do Império - da qual provinham apenas as estátuas a D. Pedro I ( 1862) e José Bonifácio (1872), ambas do escultor francês Louis Rochet ${ }^{82}$-, contribuindo para um clima de expectativa em relação ao futuro da cidade.

Em segundo lugar, devemos considerar o tom retórico e exagerado assumido pelos primeiros autores ao criticar a estatuomania, revelando uma preocupação em se sintonizar aos discursos estrangeiros identificados como a marcha do progresso e da civilização. Nesse sentido, esses autores repercutiam em seus textos a fórmula empregada nas publicações francesas, que denunciavam a estatuomania como um movimento que atingia não só Paris, mas também os pontos mais interioranos da França. Nas palavras de Jayme de Távora, em 1906: "não há cidade, não há aldeia, não há lugarejo, que não queiram ter o seu grande homem, o seu herói, o seu semideus" . ${ }^{83}$ Tal fórmula, por sua vez, tinha muito menos vigência para o Brasil, onde o Rio de Janeiro reuniu os principais projetos escultóricos do momento. A menção à expansão geográfica foi sendo suprimida nos artigos posteriores sobre o tema, tornando-se menos retóricos e mais realistas ao abordar a escultura pública carioca.

\section{A ESTATUOMANIA E A LUTA POLÍTICA}

A constatação de que não havia no Rio de Janeiro um número de estátuas comparável a Paris trouxe implicações para a abordagem do problema no Brasil. Nos comentários publicados tanto na imprensa francesa como na brasileira, a estatuomania na França era entendida como um excesso, uma pulsão comemorativa não saciada após celebrar os personagens considerados de legítimo mérito. Dessa maneira, a sanha escultórica prosseguia, promovendo a inauguração de monumentos homenageando repetidamente os mesmos sujeitos ${ }^{84}$ ou rendendo tributo a figuras de medíocre relevância.

Diferente dos artigos que comentavam a situação das cidades francesas, as críticas à estatuomania voltadas à realidade brasileira expressavam descontentamento com os personagens representados ou que se pretendia representar no bronze e no mármore. Questionava-se a escolha de personalidades consideradas pelo articulista da vez como secundárias em nossa história, enquanto outras, a quem se atribuía maior relevância, eram esquecidas. Se na França questionamentos desse tipo eram uma dentre tantas críticas à statuomanie, ${ }^{85}$ no Brasil eles ocuparam o primeiro plano. Para esses autores não se tratava de uma proliferação infindável de obras escultóricas pelas cidades, mas uma monumentalização de figuras vistas como não a partir de um olhar para a França, foi um artigo publicado em 1894, assinado com o pseudônimo de Fantásio.

77. Flaminio (1901, p. 3, grifo nosso).

78. Távora (1906, p. 33-34, grifo nosso).

79. O Imparcial (1913, p. 2).

80. Peralta (1924, p. 2, grifo nosso).

81. FR. (1924, p. 2, grifos nossos).

82. Knauss, op. cit., 2010.

83. Távora, op. cit., p. 33.

84. A respeito das homenagens repetitivas, podemos citar como exemplo o artigo já mencionado de Garcia Redondo, sobre a estátua de Musset em Neully-sur-Seine: "a nova estátua do poeta, que eu já contemplei também, é toda de mármore de Carrara e, a meu ver, bem superior à outra, inexpressiva e pretensiosa, há poucos meses inaugurada no coração de Paris". Garcia Redondo, op. cit., p. 3, grifo nosso.

85. Basta lembrarmos do artigo publicado no jornal francês $L e$ Temps, traduzido no mexicano El Partido L $i$ beral, no qual se criticava a encomenda de um busto de Guillotin para Versalhes, entre tantas figuras célebres ainda não homenageadas. 
86. Entre suas obras críticas ao novo regime republicano, em especial ao governo do marechal Deodoro da Fonseca, esteve uma série de artigos publicados em Portugal, onde estava quando da Proclamação da República, sob o pseudônimo Frederico de S, depois reunidos na obra Fastos da Ditadura Militar no Brasil. Um panorama biográfico de Eduardo Prado (18601901) pode ser encontrado no site da Academia Brasileira de Letras (sem data), da qual ele foi um dos fundadores; e no verbete do Dicionário da Elite Política Republicana (1889-1930). Silva (sem data).

87. Segundo Carneiro, o grupo formado em Paris por Santa-Anna Nery, Prado e o Barão do Rio Branco foi designado como "Santíssima Trindade Literária” por Antônio Faria, em sua biografia do escritor paraense, publicada em 1905. Carneiro, op. cit., p. 56; p. 187-188.

88. Jornal do Commercio (1907, p. 4, grifos nossos). merecedoras dessa honraria. Dessa maneira, os discursos mobilizavam a ideia de estatuomania e ao mesmo tempo reclamavam da ausência de monumentos a figuras como Tiradentes, os irmãos Andrada, os revolucionários pernambucanos de 1817, entre outros. Em síntese, podemos dizer que a estatuomania brasileira era denunciada em termos qualitativos, e não quantitativos.

Frequentemente, divergências político-ideológicas entre a imprensa - seja do articulista, seja do periódico - e o homenageado ou seu círculo políitico eram a base para questionar a legitimidade das esculturas. Por essa razão, o alvo de fortes embates era o merecimento do personagem homenageado, debate que encontrou campo fértil nas páginas dos jornais da época. Sendo assim, os discursos contrários à estatuonomia no Brasil são inseparáveis da luta e tensões políticas.

Um dos alvos dessa disputa foi o escritor Eduardo Prado, nascido no seio de uma tradicional família paulista, monarquista que combateu o novo regime republicano em alguns de seus escritos, ${ }^{86}$ sendo bastante próximo do já citado Santa-Anna Nery. ${ }^{87}$ Em 1907, poucos anos após sua morte, o diário fluminense Jornal do Commercio repercutiu uma polêmica, iniciada no periódico paulistano $O$ Estado de $S$. Paulo, a respeito da proposta de se construir uma herma a Eduardo Prado na capital paulista. Nesse embate, o conceito de estatuomania fora mobilizado para questionar a legitimidade da homenagem ao escritor. Em 26 de outubro, o Jornal do Commercio publicou uma carta dirigida à redação do jornal paulistano, transcrita a seguir:

São Paulo. A propósito da estátua de Eduardo Prado, escreveram o seguinte ao Estado de S. Paulo: 'sr. redator - alguns moços, em um movimento de ingênuo entusiasmo, trouxeram a público a ideia de levantar uma estátua a Eduardo Prado. Não há, por certo, Paulista algum que negue ao brilhante escritor e erudito investigador da nossa história qualidades que o destacam com muito relevo dos homens da sua geração. Mas, é também verdade que essas qualidades do saudoso Paulista, nunca se objetivaram em uma ação social capaz de justificar essa homenagem [...]. As estátuas ou hermas erigidas na praça pública não podem ser, evidentemente, a expressão das simpatias pessoais de uma minoria e sim a concretização de um julgamento consagrado pelo sentimento popular e pela tradição. Não nos parece lícito que a população da capital de S. Paulo dispense a intensidade do seu entusiasmo cívico em uma verdadeira estatuomania a vultos secundários, quando ainda conserva a linda esplanada do Ipiranga sem o grandioso monumento que deve perpetuar a ação do maior dos Paulistas na Independência da Pátria. Que essa mocidade de tão generosos sentimentos ouça esta noite a palavra erudita de Oliveira Viana e nos diga depois se não temos razão. O busto de Eduardo Prado poderia figurar no nosso Instituto Histórico, se já ali houvesse o de Varnhagen. Mas, a sua estátua ou a de qualquer outro não se justifica enquanto não erigirmos em frente ao palácio do lpiranga o monumento dos Andradas, tendo por figura principal o Grande Patriarca, e, em plano inferior, os medalhões de Martim Francisco e Antonio Carlos, completando a nobre trindade cívica, e José Bonifácio (o moço), o orador eloquentíssimo, o poeta mavioso e o dedicado abolicionista' ${ }^{88}$ 
Como vemos, o articulista anônimo, em sua carta endereçada ao jornal, questiona a legitimidade da herma a Prado, considerando-a uma "uma verdadeira estatuomania a vultos secundários", confrontando-a com a carência de um monumento à Independência - especificamente, aos irmãos Andrada - no lpiranga. Não menciona nem se contrapõe aos posicionamentos políticos de Eduardo Prado, os quais, no entanto, não deixariam de ser um ingrediente desse discurso, em face ao seu recente falecimento. A resposta a essa publicação, naturalmente, não demorou a chegar. No dia seguinte, a 27 de outubro, o Jornal do Commercio publicou a resposta dos defensores da homenagem a Prado, dessa vez, com autoria assinalada: Afonso Arinos. ${ }^{89}$

S. Paulo. A respeito do projeto de uma estátua a Eduardo Prado, o Dr. Afonso Arinos escreveu o seguinte ao Estado de S. Paulo: "Sr. Redator - Acabo de ler o vosso entrelinhado inserto nas 'Notas e informações', em que vos opondes à ideia de uma herma a Edvardo Prado, considerando-a 'expressão de simpatias pessoais de uma minoria', pois não vos 'parece lícito que a população da Capital de S. Paulo dispense o entusiasmo cívico em uma verdadeira estatuomania a vultos secundários'. Basta essa citação para ver que o escritor do entrelinhado guarda contra a memória do inolvidável paulista um ressaibo das mal orientadas paixões que atribui a Eduardo Prado na maioria de suas obras, com a única exceção das Viagens. Estatuomania, quando em mais de 20 anos, apenas uma pobre herma se erigiu nos nossos jardins! É caso de dar parabéns ao autor do entrelinhado, porque, só conhecendo as Viagens, pode ainda ter o raro e finíssimo prazer da leitura da llusão Americana, da conferência sobre o Catolicismo, a Companhia de Jesus e a colonização do Novo Mundo, dos discursos no Instituto Histórico do Rio e no de S. Paulo, do capítulo imortal sobre o padre Manoel de Moraes, que Ramalho Ortigão considera uma síntese perfeita da Renascença portuguesa; da Polêmica, que tão funda impressão deixou em todos os espíritos e da admirável monografia sobre a Arte no Brasil, escrita em francês e reunida no volume sobre o Brasil na exposição francesa de 1889". ${ }^{90}$

Em sua resposta Arinos procurou, por um lado, rebater a acusação de que a herma a Prado se constituiria numa estatuomania, lembrando a carência de grandes obras escultóricas em São Paulo. Por outro lado, e com mais empenho, buscou rechaçar o rótulo de "vulto secundário" a Prado, apresentando uma lista de seus trabalhos literários, que iam muito além das Viagens citadas pelo crítico. Se o articulista anônimo se calou sobre as tensões políticas que rondavam a figura do futuro homenageado, Arinos as reconheceu abertamente, porém as minimizou, convertendo-as em uma virtude:
89. Afonso Arinos (18681916), nascido em Minas Gerais, iniciou o curso de Direito em São Paulo em 1885, transferindo-se depois para Ouro Preto, então capital mineira. Sua proximidade com Eduardo Prado pode ser atestada pelo convite que recebeu, em 1897 , para dirigir o Comércio de São Paulo. Assumiu a cadeira de Eduardo Prado na Academia Brasileira de Letras, após seu falecimento. Cf. site da Academia Brasileira de Letras.

90. Jornal do Commercio (1907, p. 4, grifos nossos). 


\section{Ibid.}

92. Júlio Porto-Carreiro (1887-1937) depois se destacaria como médico psiquiatra. Formado na Faculdade de Medicina do Rio em 1910, atuou no Hospital Nacional de Psicopatas, onde provavelmente teve contato com a obra de Freud. Sobre sua atuação nesse campo, Cf. Castro (2015).

93. O caricaturista e pintor ítalo-brasileiro Angelo Agostini (1843-1910) tornou-se conhecido, entre outros aspectos, por suas sátiras da Guerra contra o Paraguai e as obras apresentadas nos Salões de Belas Artes da Academia, que representavam temas históricos - como a tela $A$ baralha do Avaí (1872-1877), de Pedro Américo -, bem como a denúncia às torturas da escravidão. Sobre Agostini, ver o verbete na Enciclopédia Itaú Cultural (2017).

94. Porto-Carrero (1911, p. 2).
O vosso articulista considera com desprezo obras de destruição, de certo os Fatos da ditadura militar, e outras, em que ele abnegadamente, fugindo a posição e a lucros fáceis na partilha dos despojos que a República proporcionou com mãos largas a quantos dela se acercaram, se revoltou intrepidamente contra erros e violências, hoje reconhecidos e confessados, sem exceção, pelos grandes dignitários do novo regime, em seu início [...]. A D'Anvers, por um soneto, um único, mas admirável, erigiu a França uma estátua e não nos parece que a grande nação latina seja inferior em cultura a S. Paulo [...]. Desculpe-me, sr. Redator, este protesto em quem não quer ver no vosso articulista simplesmente o ardor, ora despertado, de antigas cicatrizes.91

A desaprovação a um projeto escultórico com ressonâncias políticas, acusando-o de celebrar um personagem secundário, voltaria à baila poucos anos depois nas páginas do mesmo Jornal do Commercio. Em 1911, por ocasião da morte de Francisco Pereira Pinto (1817-1911), Barão de Ivinheima e oficial da Armada Imperial que havia participado da Guerra da Tríplice-Aliança contra o Paraguai, Júlio Porto-Carrero 92 publicou um texto, em cujos primeiros parágrafos foi crítico à "banalização" da condição de herói em seu tempo, no qual atitudes corriqueiras eram exaltadas, enquanto feitos extraordinários eram desprezados. Uma manifestação desse problema, segundo Porto-Carrero, era a incapacidade de priorizar os heróis e acontecimentos em sua opinião dignos de uma comemoração escultórica. Nesse sentido, condena uma suposta proposta de homenagem ao caricaturista Angelo Agostini, ${ }^{93}$ morto no ano anterior, apresentando uma lista daqueles que deveriam the anteceder no bronze ou no mármore:

Por outro lado, para dar que fazer aos artistas e para encher as praças vazias fazem-se monumentos; nesses monumentos glorificam-se bonecos de bronze, ou simples candelabros da Light, ou as sogras, ou até mesmo heróis verdadeiros. Em Paris, com a célebre "estatuomania", chegou-se ao ponto de glorificar em vida e em estátua o maestro Saint-Saëns. Entre nós, até Angelo Agostini vai ser imolado em bronze e em herma! A injustiça é a tal ponto clamorosa, que se esquecem nomes mais gloriosos do que o do glorioso abolicionista pintor - caricaturista. A modéstia de Agostini vibraria se ele pudesse ainda saber do atentado. E lembraria que Castro Alves, "poeta dos escravos", ainda não tem estátua, nem o gigantesco Patrocínio, nem o sublime Nabuco. Lembraria que a Arte da Pintura tem representantes mortos que, incontestavelmente, the são superiores. E lembro eu ainda que não temos um monumento aos precursores republicanos de 1817, de Pernambuco, nem ao Tiradentes, nem àqueles titãs que foram os bandeirantes de S. Paulo, nem a Mem de Sá, o fundador; e que no que respeita à história, à História verdadeira e grande ficamos na glorificação do descobrimento, da Guerra do Paraguai e da fundação da República. ${ }^{94}$

Contudo, as próximas palavras do articulista incorreriam em uma contradição. Conclui o seu texto exaltando a figura do Barão de Ivinheima, reivindicando ao recém-falecido a condição de herói e sinalizando para o seu monumento futuro: 
Heróis, temo-los. E tanto mais quanto mais para o passado. $\bigcirc$ que é preciso é apreciá-los devidamente, e não desvalorizar o que já anda por um tão baixo preço. E é esse baixo preço que me contrista, e é por ele que me exalta ver entrar no advento solene do Passado esse vulto de herói deveras que foi o Barão de Ivinheima. Entra quase centenário, vestido de glória [...]. Heróis como esse, sim, têm já na sua estatura moral o molde do seu bronze futuro. Falta apenas o artista que o realize. ${ }^{95}$

A acusação de estatuomania para deslegitimar monumentos por razões político-ideológicas transcendeu o terreno dos desafetos políticos mais imediatos. Em 1935, o jornalista e escritor Carlos Maul, 96 por ocasião do centenário de nascimento de Gaspar da Silveira Martins, ${ }^{97}$ publicou no jornal Correio da Manhã um artigo em que repercutia e endossava o discurso de homenagem do deputado Demétrio Xavier na Câmara dos Deputados, tecendo severas críticas ao Barão de Mauá, Irineu Evangelista de Sousa, antigo desafeto de Silveira Martins. ${ }^{98} \bigcirc$ articulista aproveitou para condenar o monumento ao Barão de Mauá:

Quando vejo o seu monumento, penso instintivamente na estatuomania, daquela sátira dos Pamphletos do último dia de Carlyle, sobre o busto de um certo Hudson, rei de caminhos de ferro na Inglaterra... Mauá foi também aqui um rei de ferrovias, mas por conta de terceiros. A ele devemos a entrega de numerosas fontes de riqueza a mãos estranhas. Amigo incondicional dos governantes, ele sabia desenvolver as suas habilidades no sentido de obter concessões com garantia de juros que ia transferindo aos gros-bonnets da finança cosmopolita, mais interessados nos lucros do seu capital, o que era lógico, do que no progresso brasileiro. ${ }^{99}$

Maul cita o livro do escritor inglês Thomas Carlyle, Latter-day Pamphlets (1850) [Panfletos do último dia], em cuja obra há um texto crítico à construção de um busto a uma personalidade que o autor considerava indigna da homenagem. ${ }^{100}$ Esse texto foi uma importante referência para os críticos da estatuomania brasileira e já havia sido citado por Carlos Maul em artigo publicado em 1918. ${ }^{101}$ Assim como Carlyle em relação à homenagem a Hudson, Maul questiona a legitimidade do monumento a Mauá, "homem de negócios do Segundo Império pelo calor dos governos".

A denúncia da estatuomania se deu não apenas sob as duras palavras escritas em jornais, mas também foi debatida e satirizada por imagens, principalmente em revistas ilustradas e humorísticas, questionando a legitimidade das estátuas e dos concursos. Ainda na seara das críticas político-ideológicas à monumentalização de determinados personagens, em agosto de 1919 a revista carioca D. Quixote publicou uma charge ironizando a urgência de se construir
95. Ibid., grifo nosso.

96. Carlos Maul (18871973), intelectual de tendências nacionalistas, teve uma atuação bastante forte na imprensa fluminense. Sobre ele, Cf. Caires (2018).

97. Silveira Martins (18351901) assumiu cargos políticos de destaque durante o Segundo Reinado, sendo deputado provincial e geral, senador, ministro da fazenda e presidente da província do Rio Grande do Sul. Após retornar do exílio, que se seguiu à Proclamação da República, integrou-se ao Partido Federalista gaúcho e atuou na Revolução Federalista (1893-1895). Cf. verbete do Dicionário da Elite Política Republicana (18891930). Luna (sem data).

98. "Na Assembleia-Geral envolveu-se em uma contenda com Irineu Evangelista de Sousa, o futuro barão de Mauá, membro do Partido Liberal e deputado geral pelo Rio Grande do Sul, acusando-o de apoio ao gabinete conservador de José Maria da Silva Paranhos (1871-1875), o visconde de Rio Branco, o que acabaria por levá-lo a renunciar ao cargo em 1873". Cf. Arquivo Nacional - MAPA (2020).

99. Maul (1935, p. 4).

100. Carlyle (1850, p. 216248).

101. Maul (1918, p. 4). 
102. João Paulo Lemmo Lemmi (1884-1926), conhecido como Voltolino, foi um caricaturista e ilustrador paulistano que atuou em importantes revistas, como O Malho, A Cigarra, Revista do Brasil, entre outras. Cf. verbete na Enciclopédia Itaú Cultural (2017). um monumento a Francisco de Paula Rodrigues Alves (1848-1919), falecido em janeiro do mesmo ano, após ser eleito presidente para um novo mandato, mas não tomar posse.

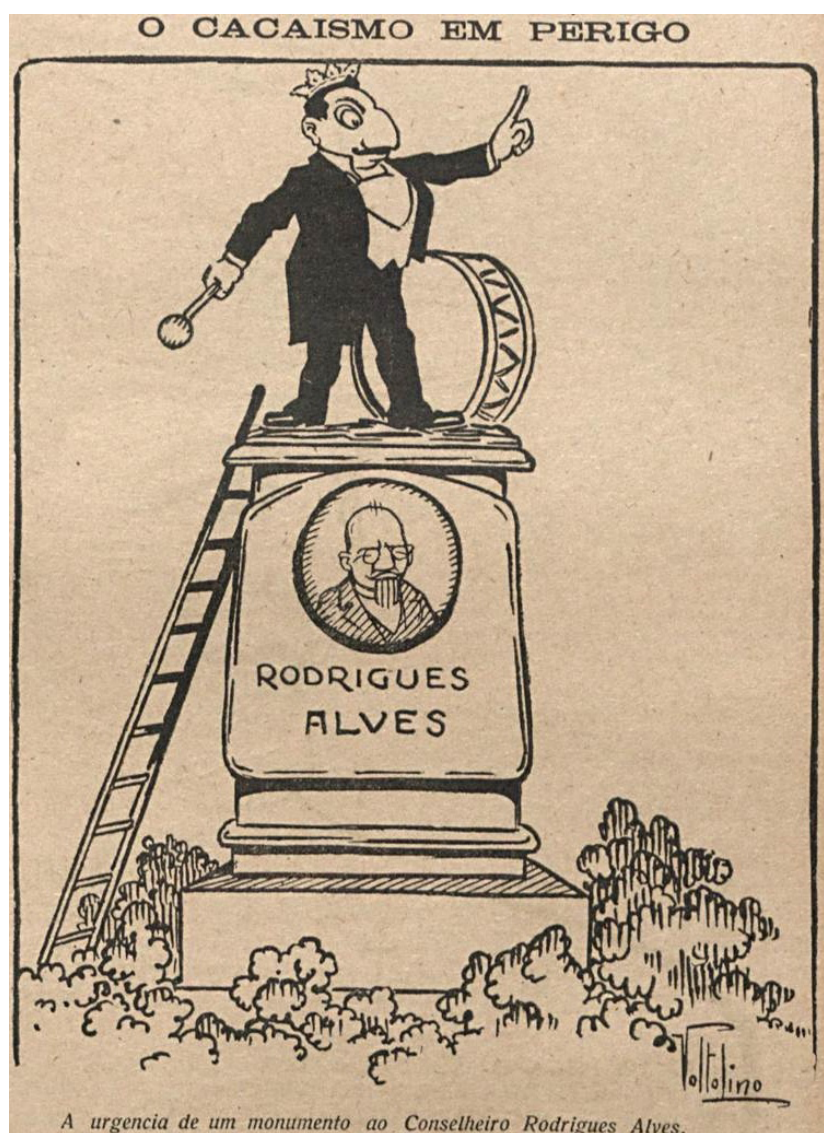

Figura 1 - Charge de Voltolino, "O Cacaismo em perigo". Fonte: D. Quixote, (1919, p. 23). Biblioteca Nacional (BNDigital).

Analisando a Figura 1, porém, podemos ir mais longe. Vemos no desenho, assinado pelo caricaturista Voltolino, 102 um pedestal, em cuja face frontal está fixado um medalhão que exibe um busto. $O$ topo desse pedestal, no entanto, é ocupado não por uma estátua, mas por um homem "vivo", portando uma coroa à cabeça e em movimento de tocar um bumbo. Há uma escada apoiada junto aos pés do homem coroado, a qual provavelmente utilizou para subir ao topo.

Na verdade, o ex-presidente Francisco Rodrigues Alves, a quem a obra prestaria homenagem, é representado apenas no busto do medalhão. No topo da obra, coroado, aparece o seu filho, Oscar Rodrigues Alves. A identificação do personagem como Oscar é possível, em primeiro lugar, se confrontarmos essa imagem com outra charge de Voltolino, publicada na revista D. Quixote no mesmo ano de 1919, retratando o filho do ex-presidente de maneira idêntica, nomeando-o 
de forma inequívoca. ${ }^{103}$ Em segundo lugar, em outras ocasiões, Oscar foi designado na revista D. Quixote como "príncipe Cacá", 104 o que justificaria a coroa sobre sua cabeça e o fítulo da charge, "o Cacaismo em perigo". Confrontando a imagem com a sua legenda, "a urgência de um monumento ao conselheiro Rodrigues Alves", podemos inferir que a charge e a revista, sempre bastante crítica à figura de Oscar, interpretavam a obra não como uma homenagem que interessava ao já falecido pai, mas sim a seu filho, ainda atuante na cena políica. A escada aos seus pés reforça a ideia do esforço de Oscar por se promover a partir da homenagem ao pai.

A charge em D. Quixote não se tratava de um posicionamento crítico frente uma suposição. Avançava na Câmara dos Deputados, naquela ocasião, um projeto para erigir um monumento ao recém-falecido presidente, o que explica a menção a uma "urgência" da iniciativa. Em julho de 1919, noticiou o jornal O Paiz:

\begin{abstract}
Monumento a Rodrigues Alves: $O$ sr. Nicanor Nascimento fundamentou ontem, à hora do expediente, na Câmara dos Deputados, o segundo projeto de lei, recebido por essa casa legislativa com evidentes demonstrações de solidariedade e apoio: "considerando que: al a cidade do Rio de Janeiro era, quando o dr. Francisco de Paula Rodrigues Alves assumiu o governo da República, de triste aspecto colonial; b) sua ação decisiva, sistemática, [...], transformou-a numa cidade de suprema beleza, [...] e) as ações dos grandes homens devem ser perpetuadas em monumentos imperecíveis - não só para prêmio às altas virtudes, mas também para educar as gerações por vir e incentivá-las para os grandes atos de patriotismo; proponho o seguinte projeto de lei: $O$ Congresso resolve: Art. $1^{\circ}$. O poder executivo fará erguer em uma das praças do Distrito Federal, dentro de dois anos, um monumento que perpetue a memória do cidadão Francisco de Paula Rodrigues Alves em que a estátua deste benemérito brasileiro seja motivo principal." 105
\end{abstract}

\section{AS ESTÁTUAS COMBATIDAS COM HUMOR}

Para desqualificar determinadas estátuas ou a estatuomania de maneira geral, muitos críticos mobilizaram o humor, seja por meio da sátira políitica, seja por charges publicadas nas revistas ilustradas. ${ }^{106} \mathrm{O}$ humor torna-se um componente essencial da crítica aos monumentos à medida em que descontrói e esvazia a aura de sacralidade que ronda essas obras escultóricas, materializada no pedestal e no gradil, que impõem distanciamento e hierarquia, obrigando o observador a contemplá-las olhando para cima, de uma posição inferiorizada. ${ }^{107}$ Mobilizando o humor, as críticas publicadas nas revistas se direcionavam não apenas a um projeto escultórico em particular, mas se voltavam de forma abrangente contra as homenagens a figuras
103. Trata-se de uma charge intitulada $O$ caso do monumento da independência, que retrata um diálogo entre Oscar Rodrigues Alves e Altino Arantes, diante dos projetos para o Monumento à Independência no Ipiranga, em São Paulo. "Altino: Mas, Oscar, você entende de concursos de maquetes? Oscar: Você vai ver... essa fazenda é comigo". Voltolino (1919, p. 23).

104. "Está entre nós o Dr. Oscar Rodrigues Alves, o príncipe Cacá, filho do conselheiro Rodrigues Alves" [grifo nosso]. D. Quixote (1917, p. 11). Também aparece como "príncipe Kaká", em marcante tom irônico: "Passou a 16 do corrente, quarta-feira, o aniversário do sr. dr. Oscar Rodrigues Alves, 'né' príncipe Káká. Sua ex-Alteza fez anos incógnito". D. Quixote (1921, p. 18, grifo nosso).

105. O Paiz (1919, p. 5, grifo nosso).

106. Uma reflexão de fôlego a respeito do humor nos primeiros anos da República é desenvolvida em: Saliba (2002).

107. Sobre os significados simbólicos do pedestal, Cf. Maderuelo (1994). 
entendidas como desprovidas do devido mérito. É o caso da charge apresentada na Figura 2, publicada em D Quixote no ano de 1923, intitulada "A polícia não errou".

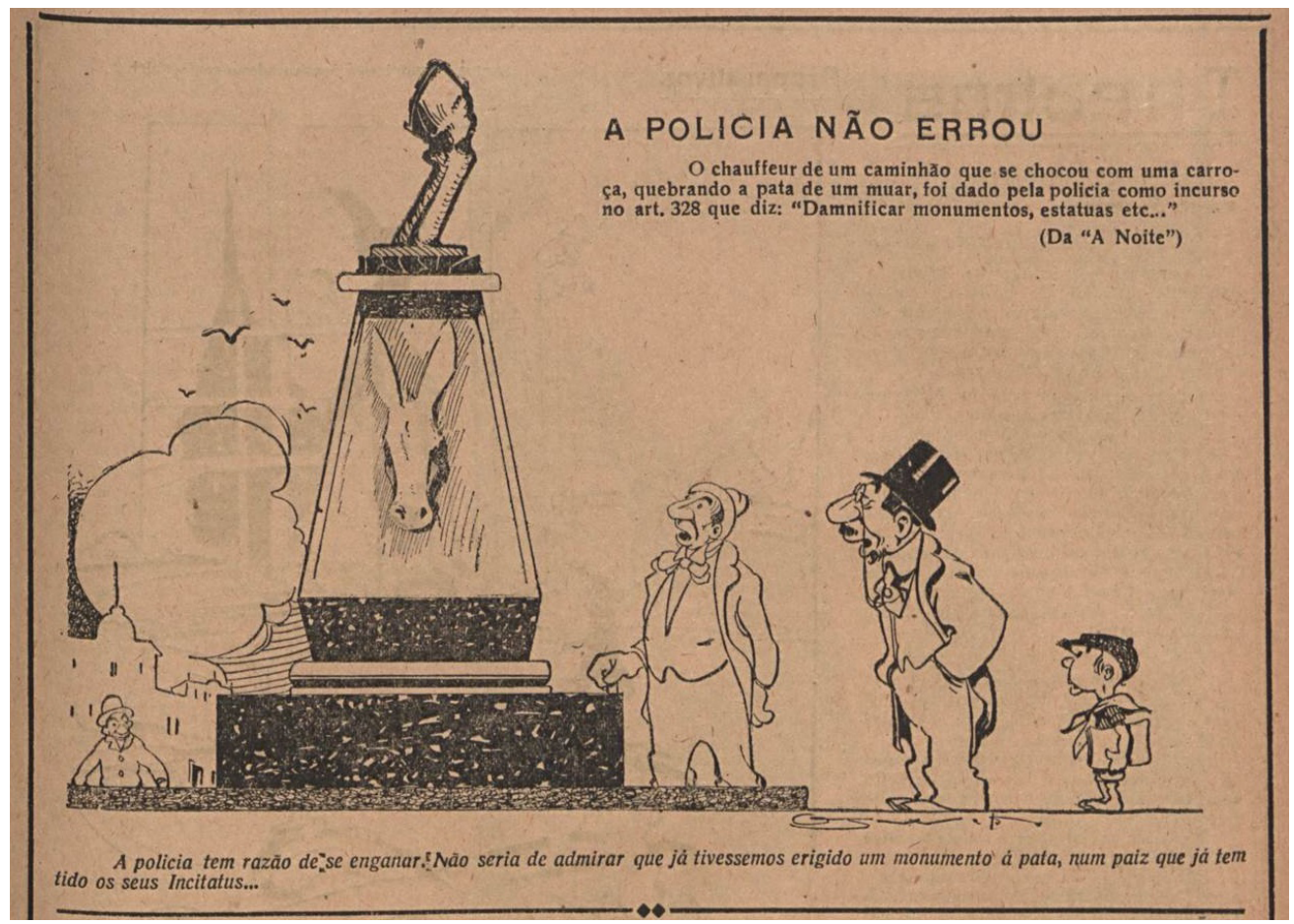

Figura 2 - Charge "A polícia não errou". Fonte: D. Quixote (1923, p. 17). BNDigital.

Na imagem, sem assinatura, vemos o pedestal ocupado por um pilar - no qual está gravada a figura de um muar -, encimado por uma estátua que representa a pata de um animal. Para compreender o seu sentido, é preciso considerar o texto que a acompanha:

O chauffeur de um caminhão que se chocou com uma carroça, quebrando a pata de um muar, foi dado pela polícia como incurso no art. 328 que diz: "Danificar monumentos, estátuas etc..." (Da A Noite). A polícia tem razão de se enganar. Não seria de admirar que já tivéssemos erigido um monumento à pata, num país que já tem tido os seus Incitatus.

Desse modo, a charge faz uma crítica às estátuas que homenageavam pessoas que supostamente não as mereciam, podendo comparar esses tributos ao oferecido a um animal ferido. A referência a Incitatus, o cavalo do imperador romano Calígula que gozava de diversas regalias e que teria sido nomeado cônsul, é bastante significativa. 
No mesmo sentido, Fon-Fon! foi mais longe. Em 1909, essa revista ilustrada carioca abriu um concurso de projetos escultóricos inusitado: o propósito era homenagear Adão e Eva. Na primeira matéria sobre o concurso, em meio ao caráter jocoso da publicação, podemos captar o seu tom crítico à estatuomania e à dignidade das figuras homenageadas.

\begin{abstract}
Um concurso necessário. Ingratidão universal. Injustiça do destino. Não há precursor de ideia ou de invento que, depois de morto, não merece a consagração de uma Estátua. As ruas e praças estão cheias destes símbolos da gratidão nacional para com aqueles que deixaram, no ativo da sua existência, qualquer cousa que possa concorrer para o engrandecimento da Pátria e da Humanidade. [...]. Ora, a Humanidade, tão pródiga e apressada em render estas homenagens a todos os vultos até de mediana saliência, tem-se esquecido de rendê-la a duas individualidades, não direi de notável saber, mas de indiscutível utilidade. Sim! Basta dizer que, se não fossem elas, a humanidade não existiria e este mundo continuava a ser o caos horrendo que era antes da sua aparição [...]. Fon inicia hoje orgulhosamente o Concurso de maquettes para a elevação de uma Estátua aos dois sublimes vultos patriotas que na História tiveram o nome de ADÃO e EVA. ${ }^{108}$
\end{abstract}

Se todos aqueles que deixavam uma dívida de gratidão deviam ser celebrados em estátuas, inclusive os de "mediana saliência", argumenta o articulista, nada mais justo que os "pais" da humanidade também recebessem honraria. A seguir, mantendo-se o tom burlesco, são elencadas as regras do concurso, mimetizando os certames realmente abertos àquela época e anunciados nos periódicos: condições e prazos para os artistas se inscreverem, localização da futura obra, orientações para a representação dos homenageados etc.

Assim, para concorrer não é preciso ser especialmente estatuário. Todos podem concorrer: o estatuário, o arquiteto, o pintor, o poeta, o político, o médico, a parteira, o farmacêutico, etc. etc. As maquetes podem representar os nossos venerandos pais ADÃO e EVA antes ou depois do Pecado, guardadas as reservas exigidas pela moralidade do assunto. [...] A maquete premiada, conforme escolha do júri especialmente organizado para este fim, será [...] colocada no ponto do Globo terrestre, que um Congresso de sábios, também especialmente indicado para este fim, indicar como sendo o meio do mundo. $O$ autor da maquete premiada terá o seu retrato publicado nas colunas de Fon-Fon e receberá um prêmio, que ainda não está escolhido.

Sobre a composição do júri, o articulista apresenta uma lista que vai das mais altas autoridades da República, nos três poderes lum membro do Governo Federal, um Ministro do Supremo Tribunal, um Senador, um Deputado, um Governador etc.), às diferentes tendências políticas do momento ("um civilista e um 
109. Vale lembrar que o cenário político brasileiro da época era agitado pela campanha civilista promovida por Rui Barbosa, que se oporia ao marechal Hermes da Fonseca na disputa presidencial.

110. Fon-Fon! (1909, p. 16). hermista"). ${ }^{109}$ Na edição seguinte, o articulista afirmou que, em comum, todas essas altas autoridades - entre as quais apenas o presidente não teria podido assumir - tinham o mérito de "descender, mais ou menos, dos citados" Adão e Eva. ${ }^{110} \mathrm{Na}$ mesma edição, a 2 de outubro de 1909, foi informado que, diante do alegado sucesso do certame e dos pedidos recebidos, o concurso e seu resultado seriam prorrogados por mais uma semana. Finalmente, a capa da revista em 16 de outubro de 1909 estampou o "projeto" vencedor:

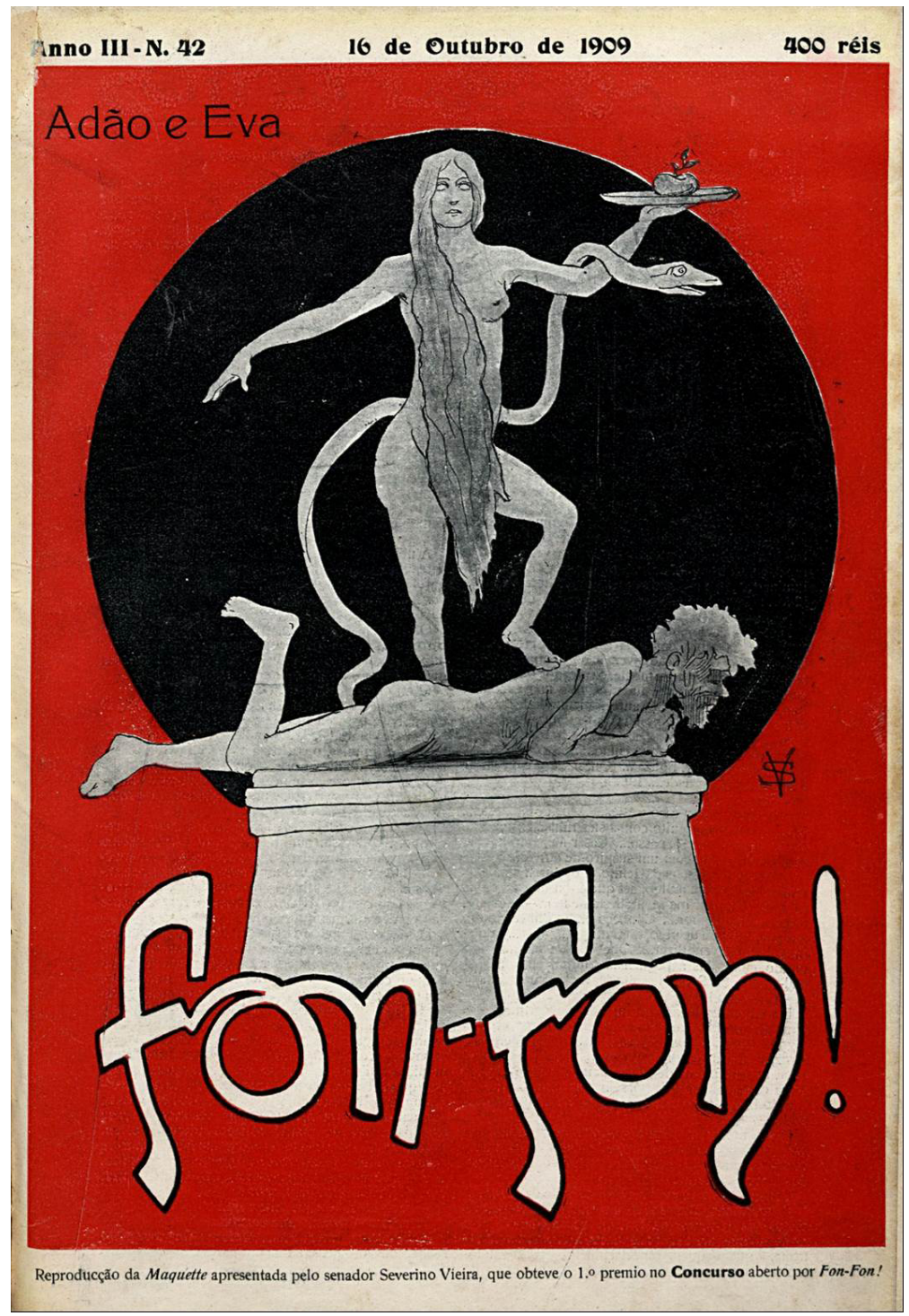

Figura 3 - "Reprodução da Maquette apresentada pelo senador Severino Vieira, que obteve o $1^{\circ}$ prêmio no Concurso aberto por Fon-Fon!". Fonte: Fon-Fon! (1909, capa). BNDigital. 
Além do vencedor, a revista apresentou outros quatro projetos, mencionando seus autores. Todos os projetos apresentados mobilizam o repertório de imagens associado ao casal Adão e Eva e ao pecado original: a serpente, a maçã, a nudez envergonhada (sinalizada na própria "convocação" do concurso). Nas Figuras 4a, $4 b, 4 c$ e 4d apresentamos os "projetos" e os nomes dos concorrentes.

Até terça feira última recebemos ainda quatro desenhos de concorrentes que, deste modo vieram abrilhantar ainda mais o nosso Concurso. Foram eles: O Dr. Erico Coelho: que, em nome dos divorcistas, apresentou um desenho originalíssimo em forma de herma. $\bigcirc$ Professor R. Amôedo: com uma concepção original em que se conjugam a gulodice de Adão e a insistência benévola de Eva.

João do Rio: o fino e malicioso João do Rio com um esplêndido desenho em que não se sabe o que admirar mais, se a malícia encantadora do casal paradisíaco, se o disfarce malicioso da folha de parreira; e, finalmente, o Dr. J. J. Seabra: com mais um desenho representando Adão tabarév e Eva provinciana, separados ainda pela serpente. ${ }^{11}$



O Dr. Erico Coelho

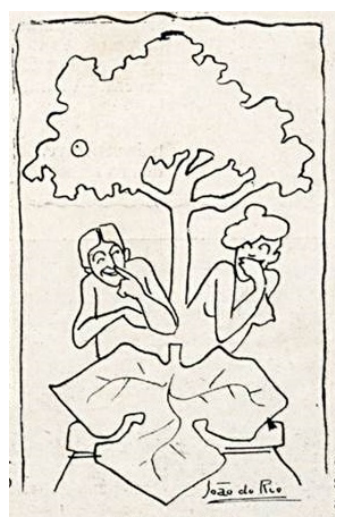

Joầ do Rio

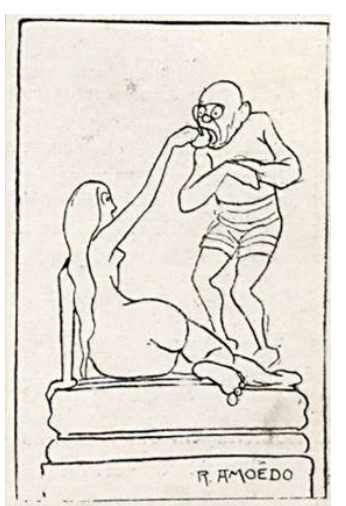

O professor R. Amoedo

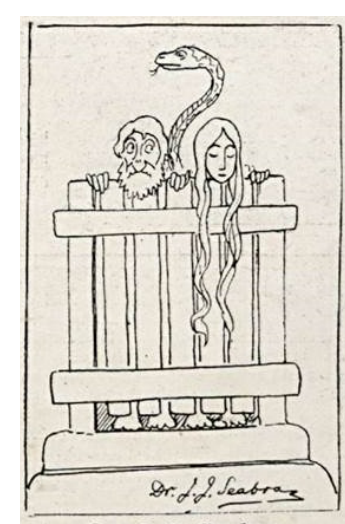

Dr. J. J. Seabra
Figuras 4a, 4b, 4c e 4d. Projetos. Fonte: Fon-Fon! (1909, p. 9); BNDigital. 
112. J. J. Seabra (18551942), político baiano, era deputado federal pela Bahia em 1909, já fora deputado constituinte em 1891, Ministro do Interior e da Justiça entre 1902 e 1906, e logo seria Ministro da Viação (1910-1912) no governo Hermes da Fonseca. Érico Coelho (1849-1922), médico e político fluminense, foi senador entre 1906 e 1909 e deputado federal entre 1909 e 1914, tendo sido também deputado constituinte em 1891. Severino Vieira (1849-1917) era senador pela Bahia em 1909, tendo sido antes deputado federal, Ministro da Viação (1898-1900) e governador da Bahia (1900-1904). Por sua vez, o piauiense Gervásio Passos (1837-1923) foi senador entre 1908 e 1915 , depois de uma longa carreira política em seu Estado natal. Cf. Verbetes do Dicionário da Elite Política Republicana (1889-1930) - FGV-CPDOC. Coutinho, Silva, Quadros e Lopes.
Pelo tom irônico assumido nessa série de publicações, temperado com sutis provocações políticas, é possível supor que todo o processo foi fantasiado pelos redatores da revista, descartando-se a participação real dos personagens citados no concurso. Esse aspecto transparece na apresentação dos componentes do júri, a exemplo de "José Veríssimo - representando a Academia de Letras, o interior do Amazonas e a instituição do seguro de vida", "J. J. Seabra, representando a intransigência hermista" e "Dr. Irineu Machado, representando o civilismo intransigente". Assim é narrada a participação de J. J. Seabra [José Joaquim Seabra, político baiano] na reunião que avaliaria os projetos:

\begin{abstract}
Reunidos todos os membros do júri [...] o sr. Dr. J. J. Seabra pediu a palavra pela ordem. $O$ júri todo tremeu, mas Sua Ex. com uma generosidade louvável, prometeu ser breve e não tratar de candidaturas presidenciais. $\bigcirc$ júri todo sossegou. S. Ex. levantando-se, disse então que era forçado a dar-se por suspeito naquele julgamento, porque tinha concorrido com dois desenhos e fazia jus ao prêmio estabelecido por Fon-Fon. Queria deste modo deixar ao júri toda a liberdade de ação. O júri com bastante mágoa, mas respeitando os motivos expostos pelo Dr. J. J. Seabra, resolveu dispensá-lo da honrosa comissão.
\end{abstract}

Cumpre mencionar que a maioria dos nomes citados - não só no júri, mas também entre os concorrentes - refere-se a políticos importantes da Primeira República que, no momento, exerciam cargos legislativos na capital ou já haviam chefiado ministérios, o que dá ao tom jocoso e às provocações políticas uma dimensão ainda mais relevante. ${ }^{112}$

Após a suposta reunião dos jurados, os premiados foram anunciados: Severino Vieira recebeu cinco votos, galgando a primeira colocação; J. J. Seabra recebeu três votos, assumindo o segundo lugar; por fim, esteve o senador Gervásio, que recebeu um único voto. $\bigcirc$ projeto vencedor, do senador baiano Vieira, tinha o título Pro Patria Laboremus, sendo descrito pelo articulista como "apoteose da mulher, tendo como embasamento o homem". Encerrando a publicação, afirmou que só faltava um sábio geógrafo definir o local exato onde estaria o "meio do mundo", para se encomendar a realização do bronze.

Se utilizar da ironia para denunciar e desmerecer estátuas consideradas sem propósito não foi uma exclusividade brasileira. Na França, em 1914, teve lugar um episódio bastante marcante, que repercutiu na imprensa carioca. Segundo o Jornal do Commercio, em edição de março de 1914, no folhetim "Ver, ouvir e contar", muitos políticos franceses, deputados e senadores, receberam pelo correio uma carta do jornalista Paul Birault anunciando-thes que organizaria um comitê para construir um monumento em homenagem a Hégésippe Simon, a quem apresentava 
como "grande precursor da democracia". A referida carta, que convidava os parlamentares a participar de uma solenidade e proferir discursos, foi respondida por seus destinatários, exaltando o grande democrata e manifestando sua simpatia, enquanto apenas alguns poucos pediram-the uma nota biográfica sobre Simon. Pouco depois, Birault publicou as cartas que recebeu dos políticos, confessando que Hégésippe Simon nunca existira, sendo apenas uma criação sua. $\bigcirc$ folhetim do jornal fluminense interpretou a peça pregada por Birault nos parlamentares franceses como uma denúncia à estatuomania:

A intenção desta peça carnavalesca não deixa de ser espirituosa. Há muito tempo que se protesta em França contra a estatuomania que tem grassado neste país, sobretudo desde o advento da República radical. A França está cheia de mármores e bronzes glorificando, a par de algumas glórias autênticas, um número considerável de mediocridades que representaram um certo papel político no seu tempo, mas cuja memória se diluiu já nas brumas do passado. [...]. Foi para protestar a seu modo contra essa extrema facilidade em conceder a personagens, que a ela não têm direito incontestável, a mais alta homenagem que se pode outorgar a uma individualidade humana, que o jornalista Birault inventou Hégésippe Simon [...]. Hégésippe Simon passou de agora em diante a ser um símbolo. O seu nome viverá sem dúvida mais tempo na memória dos homens do que os de muitos 'estatuificados' que existiram realmente. ${ }^{113}$

$\bigcirc$ texto assinado por Alter ego, um dos pseudônimos do escritor português Jayme de Séguier, correspondente na Europa e colaborador do Jornal do Commercio, não foi o único a interpretar como denúncia a peça de Birault, os diários franceses também engrossaram esse coro, conforme a nota publicada por Gustave Téry:

Entre tantos mármores e bronzes que não representam senão uma pequena vaidade dupla, o monumento de Hégésippe Simon simbolizaria e nos recordaria constantemente esses dois flagelos da atualidade: a statuomanie e a verbomanie. E se ele chegasse a nos inspirar aversão, Hégésippe Simon não seria somente um "precursor da democracia", mas um benfeitor da humanidade. ${ }^{114}$

\section{SEMPRE NAQUELA MESMA INCÔMODA POSIÇÃO}

Para além da inconformidade com as personalidades homenageadas, seja por considerá-las "vultos secundários", seja por abertas desavenças políticas, a crítica às estátuas se manifestou também no âmbito plástico, pois muitos comentários
113. Alter Ego (1914, p. 1, grifos nossos).

114. Téry (1914, p. 1). (No original: "Parmi tant de marbres et de bronzes qui ne représentent rien qu'un peu de vanité double, le monument d'Hégésippe Simon symboliserait et nous rappellerait sans cesse ces deux fléaux du temps présent: la statuomanie et la verbomanie. Et s'il parvenait à nous en inspirer le dégoût, Hégésippe Simon ne serait pas seulement un 'précurseur de la démocratie', mais un bienfaiteur de l'humanitê'). 
115. Consultado em: Bilac (1941, p. 464, grifos nossos). ironizavam a posição dos personagens representados, sugerindo quão incômoda ela seria se estivessem vivos. Nesses textos, as estátuas eram representadas como uma continuidade do homenageado falecido, que encaravam como uma espécie de "castigo" sua posição imóvel, sua localização na cidade, seus observadores etc. Mais do que os articulistas dos jornais e caricaturistas das revistas, quem bem capturou essa dimensão foi o poeta Olavo Bilac (1865-1918), ao se referir à estátua de João Caetano (1 808-1863) (Figura 5) no Rio de Janeiro, então situada na Travessa das Belas-Artes. Essa obra, do escultor Chaves Pinheiro, representa o ator segurando um punhal, em uma de suas atuações cênicas. Diz Bilac, em seu poema Fantasia:

Meia noite. Na travessa de Belas Artes. Lua clara, muito alta, entre nuvens esgarçadas. [...]. João Caetano, muito baixo no seu baixo pedestal, perna direita esticada, sombrolho [sic] franzido, estende tragicamente para as bandas do largo do Rocio o braço armado de um punhal... E, em torno dele raios brancos de luar bailam e palpitam. E de sua boca, ó espanto! sai uma voz, que soluça longamente no silêncio da noite.

$[\ldots]$

- Por que é que com o punhal que sustenho entre os dedos,

Não posso na nudez desta travessa escura,

Dar um ponto final à minha desventura?!...

Hirto e gelado, só com o meu profundo tédio

Deixo o apagado olhar correr de prédio em prédio!

Ermo tudo! E, em redor do meu tédio arrastando

O seu tédio também, andam mastins ladrando,

Passam ratos na sombra, e ouço um soldado perto,

Rondar pacatamente o quarteirão deserto...

$[\ldots]$

E, ai de mim! que tão feio e tão atarracado

Vim a vida acabar, neste beco plantado!

- Vós, que passais, dizei se há sorte tão mesquinha!

Vós, que passais, dizei se há dor igual à minha!...

Ai! como há de poder tão baixo monumento

Conter tamanha dor e tamanho tormento!... ${ }^{115}$ 


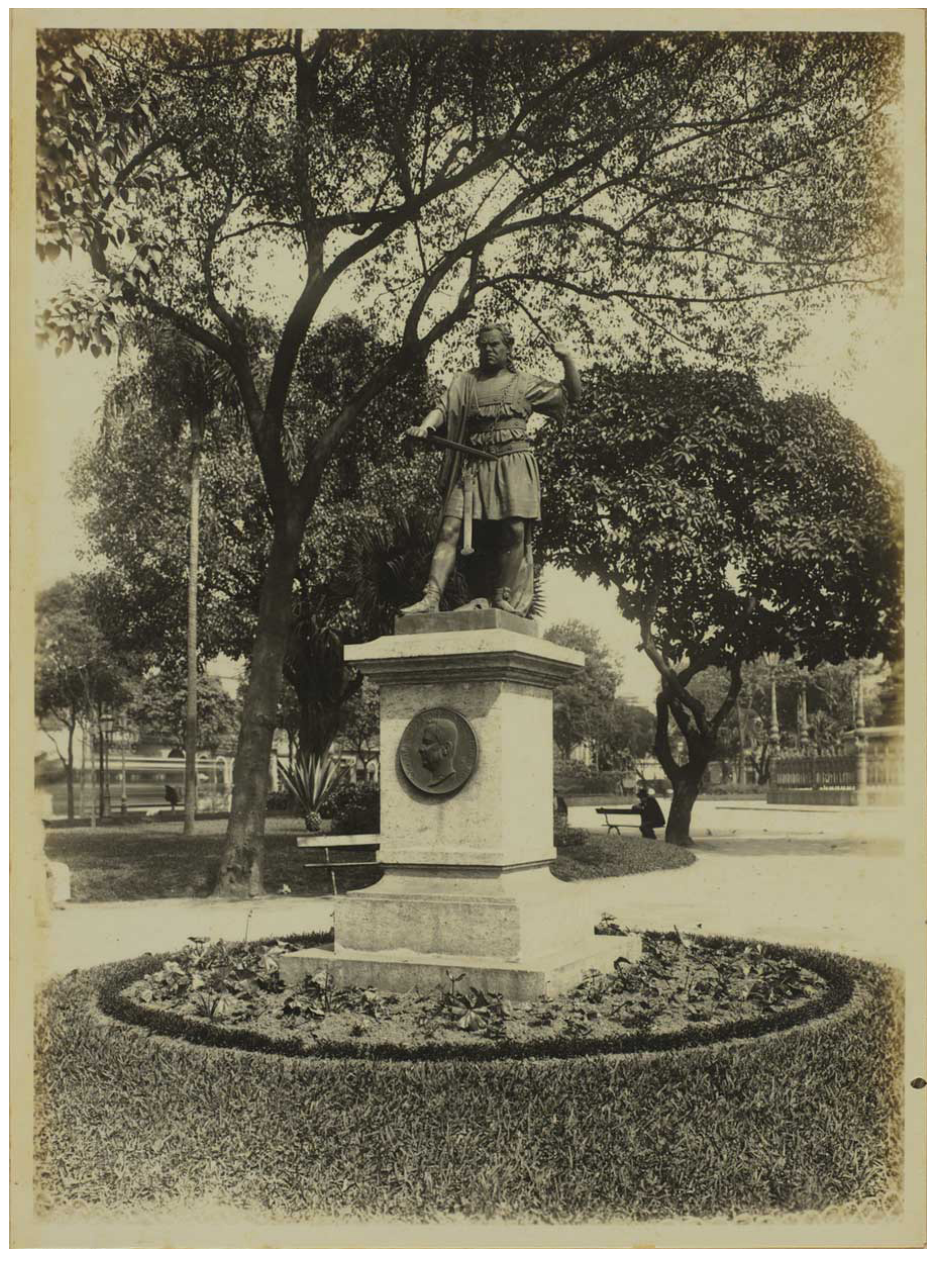

116. Sobre os pseudônimos de Bilac, Cf. Biblioteca Nacional. FBN/Série Documentos Literários (2016).
Figura 5 - estátua de João Caetano. Foto: gelatina, $\mathrm{p} / \mathrm{b} ; 23,4 \times 17,2 \mathrm{~cm}$. Colaborador do álbum: Augusto Malta. Fonte: Photographias D. Federal (1911-1920). BNDigital.

Entediada, a estátua de João Caetano lamenta não poder se suicidar, usando o punhal que carrega. Esse poema não foi a única manifestação crítica de Bilac em relação às estátuas. Em abril de 1894, assinando como Fantásio pseudônimo do poeta ${ }^{116}$-, Olavo Bilac publicou na Gazeta de Notícias um texto que via a estatuomania como um problema já vigente no Rio de Janeiro, apresentando como sintoma disso a estátua do ministro Buarque de Macedo, fundida em ferro. Nesse texto, o autor reprova a referida obra em todas as frentes possíveis: desqualifica o mérito do personagem histórico, ironiza a expressão facial da estátua e, finalmente, sua localização. Em comum com o excerto anterior, Bilac dá vida à estátua em seu texto, descrevendo-a como indignada por sua situação. Ser estátua é como uma condenação ao homenageado: 
117. Fantásio (1894, p. 1, grifos nossos).

118. Távora, op. cit., p. 33-39.

119. Ibid., grifo nosso. O largo do Rocio - então também conhecido como praça da Constituição -, onde foi instalada em 1862 a estátua equestre de Pedro I, havia sido o lugar do enforcamento de Tiradentes, em 21 de abril de 1792, condenado por sua participação na Inconfidência Mineira pela rainha $\mathrm{D}$. Maria $\mathrm{I}$, avó do imperador homenageado, $\mathrm{o}$ que resultou na tensão entre os dois personagens. Cf. Carvalho, op. cit., p. 58-78; Knauss, op. cit., 2010. Segundo Carvalho, a disputa entre a memória de Pedro I, promovida pelo governo imperial, e de Tiradentes, promovida pelos republicanos, tornar-se-ia o emblema da luta entre a Monarquia e a República. Após a Proclamação em 1889, surgiu a proposta de se construir uma estátua ao inconfidente no local, mas esse monumento acabou sendo construído diante do Palácio Tiradentes, edifício inaugurado em 1926 - no local onde antes funcionara a Cadeia Velha, na qual o mártir da conjuração mineira estivera preso. Conclui Carvalho (2017, p. 65): "D. Pedro I ficou onde estava, mas foi-lhe imposta a convivência cívica com o rival: sua praça passou a chamar-se Praça Tiradentes”.

120. Távora, op. cit., p. 3339, grifo nosso. "Mentira de bronze" foi como o liberal mineiro Teófilo Ottoni (1807-1869), líder da revolta de 1842, chamou a estátua de Pedro I. Conforme Carvalho (2017, p. 64), essa expressão virou um grito de guerra dos republicanos nos anos seguintes. Indício de como os republicanos a mobilizaram para atacar a figura do primeiro imperador e o seu monumento,
Grassa em França, como aliás em todo o mundo civilizado, dizem certos jornais, a estatuomania. A menor cidade, a mais pobre aldeia, o mais pobre burgo, querem ter um grande homem seu, perpetuado em uma estátua, vivendo essa vida de bronze, que julgamos mais duradoura que a nossa miserável existência de carne e osso. [...]. Entre nós já a mania tem grassado de quando em quando. Houve um dia em que mandamos fundir a estátua de um ministro que morreu pobre, e a quem, só por esse fato de haver morrido pobre, julgamos credor de tal apoteose. Não sei quem fez gorar o projeto. Sei que a estátua, depois de fundida, não foi levantada na praça pública: plantaram-na de pé, no meio de uma oficina de estrada de ferro, e ela ainda lá está hoje, triste, isolada, esverdeada e azinhavre. A boca da estátua permanece, há bastantes anos, entreaberta, numa interrogação a quem ninguém responde... Pobre estatua! Parece que a todos os trens que passam, roncando, sibilando, engolindo quilómetros, rolando no torvelinho da vida humana - a triste boca de bronze do ministro pobre pergunta: "Que mal vos fiz eu na terra, ó homens que nela ficastes, para que assim me tenhas condenado a esta pasmaceira perpétua?". ${ }^{117}$

Em perspectiva semelhante se posicionou Jayme de Távora, em "As estátuas no Rio de Janeiro", publicado em junho de 1906.118 Em seu longo texto de seis páginas, acompanhado de imagens, Távora faz um comentário crítico aprofundado sobre os monumentos públicos inaugurados na cidade até aquela data, ironizando as poses e gestos, as expressões faciais, o vestuário dos personagens representados. Em seu périplo pelos monumentos cariocas, Távora mantém um tom de escárnio que, em alguns momentos, cede lugar a um certo orgulho do "progresso" alcançado pela urbe, elogiando suas praças reformadas e ajardinadas, onde muitas dessas estátuas estavam instaladas.

Sobre a estátua de Pedro I, de 1862 (Figura 6), não the escapou a contradição entre o monumento e a toponímia do logradouro, rebatizado após a Proclamação da República. Diz ele: "e aqui temos agora o nosso equestre D. Pedro I, semideus da praça Tiradentes. Que ironia da sorte há nessa aproximação de nomes! - Tiradentes e Pedro I!...".119 Távora também ironizou a posição do imperador, que estende a carta constitucional de 1824, e o conjunto escultórico, em cujas quatro faces do pedestal se agrupam figuras de indígenas e animais que alegorizam os principais rios do país:

Ali está, portanto, o primeiro imperador, há já 44 anos, sempre naquela mesma incômoda posição, escarranchado num cavalo de guerra que corcoveia, entre os seus caboclos, os seus jacarés e as suas onças de bronze, e sempre com a mão estendida, oferecendo à fachada da Maison Moderne aquela Constituição, de que ninguém faz caso. Muitos estadistas do império costumam dizer que aquilo é uma "mentira de bronze!" Eles, que o diziam, é que o sabiam... ${ }^{120}$ 


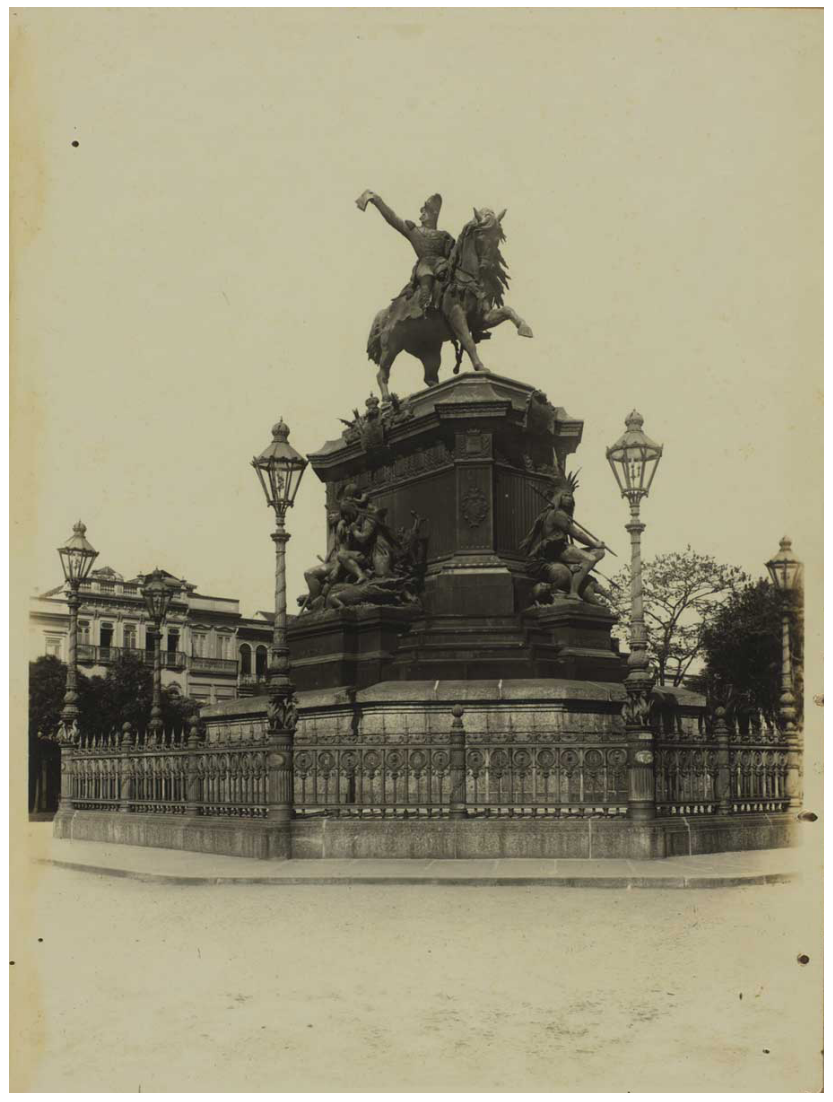

Figura 6 - Estátua equestre de Pedro I. Foto: gelatina, $\mathrm{p} / \mathrm{b} ; 23,4 \times$ $17,2 \mathrm{~cm}$. Colaborador do álbum: Augusto Malta. Fonte: Photographias D. Federal. BNDigital.

\section{Outra estátua a receber especial atenção de Távora foi a de José Bonifácio} (1872), sobre a qual o autor descarregou toda sua tinta. Aqui aparece a ideia da obra como um "castigo" para o homenageado:

O largo de S. Francisco pertence a José Bonifácio. Jesus! Como é feia a estátua do patriarca da Independência! Pequenino, atarracado, socado, apertado na sua medonha sobrecasaca de ferro, José Bonifácio, naquele monumento, que foi inaugurado em priscas eras, a 7 de setembro de 1872, parece estar ali de "castigo", como dizem, na escola, os meninos. Realmente, é um castigo aquilo. Castigo, pela fealdade da estátua, e castigo, pela serventia habitual daquela praça malfadada, que é a sede costumeira dos meetings. ${ }^{121}$

Távora estendeu sua crítica aos usos políticos que se faziam da figura de Bonifácio, com reuniões e discursos que se reuniam aos pés da sua estátua, sobretudo em momentos de crise. Acusou essas reuniões de atentados não só à ordem pública, como também à gramática: "se as estátuas têm ouvidos para ouvir, e cérebro para guardar as lições que recebem, o pobre José Bonifácio já deve ter desaprendido toda sintaxe que sabia quando vivo". contrapondo-o ao mártir inconfidente, foi o artigo "Paralello histórico", publicado no jornal Tiradentes: commemoração annual em 21 de abril 1884, assinado por Américo Werneck: "Todo o entusiasmo e toda a veneração que eu poderia sentir pela independência de minha pátria revertem sobre o mártir da conjuração mineira. 1822 foi uma burla [...]. Entre d. Pedro e Tiradentes dilata-se a distância que vai do aventureiro ao herói. D. Pedro adorava um ídolo, uma visão: o trono; Tiradentes sonhava pura e simplesmente a liberdade de sua pátria. [...]. A revolução tinha de rebentar mais cedo ou mais tarde como um acontecimento fatal; e então d. Pedro, sentindo o estremecimento subterrâneo que devia derribá-lo, como derrubaria Portugal, vestiu-se de astúcia, correu, e soltou o grito do Ipiranga. A reação que devia levantar-se contra ele tornou-se deste modo o instrumento de sua ascensão. Assim fundou-se o império [...]. E se ele [Tiradentes] não tivesse caído tão cedo, a forca enobrecida não teria cedido o lugar no Rocio àquela estátua aviltante, que, segundo a frase de Theophilo Ottoni, é realmente uma mentira de bronze. Ainda bem o povo pensa: um dia ele fará justiça” Werneck (1884, p. 3-4, grifos nossos). Importante assinalar que na primeira edição desse jornal comemorativo do 21 de abril, editado pelo Clube Tiradentes ( Carvalho, 2017, p. 66), publicou-se o artigo de Luiz Gama, "À forca o Christo da multidão”, que exalta o inconfidente e define a estátua de Pedro I como "patíbulo imperial": "o altar, as aras sacrossantas do martírio, aquele monumento mandado levantar pelo vice-rei, pelos magistrados - pelos fiéis servos da rainha foi substituido por um patíbulo imperial, modelado 
em bronze; em vez da forca há uma estátua. Desapareceu José Joaquim da Silva Xavier, para ser mais lembrado; surgiu Pedro Primeiro, o esquecido. Mudaram-se os tempos. A tragédia perdeu a sua época; a comédia entrou em voga; o lugar do mártir está ocupado pela figura do cômico; é um arlequim sobre um túmulo [...]". Gama (1882, p. 1-2, grifo nosso). Desse modo, a estátua de Pedro I foi constantemente questionada antes e depois do 15 de novembro, atacando-se o seu homenageado seja em sua condição de prócer da independência - na qual era confrontado com Tiradentes -, seja em alusão ao caráter autoritário da outorga da Constituição de 1824 - mencionada por Távora. Sobre o engenheiro fluminense Américo Werneck (1855-1927), defensor de ideias republicanas desde o período imperial em diversos periódicos, eleito deputado estadual pelo Rio de Janeiro em 1892 e depois deputado federal entre 1906 e 1908, Cf. verbete do Dicionário da Elite Política Republicana (1889-1930). Pinheiro (sem data). Sobre o poeta, jornalista e advogado autodidata Luiz Gama (1830-1882), ativista republicano e abolicionista, ver Ferreira (2007).

121. Távora, op. cit., p. 3339, grifo nosso.

122. Ibid., grifo nosso.

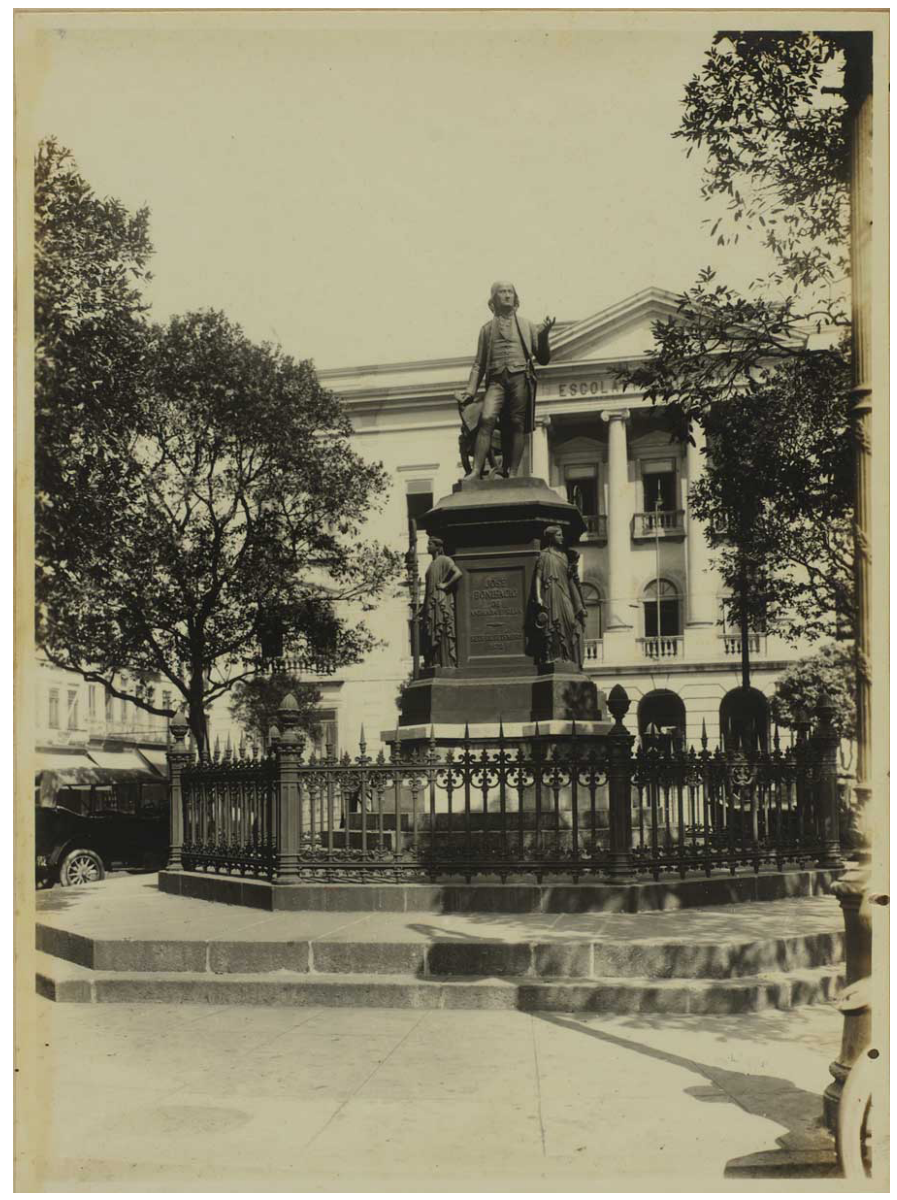

Figura 7 - Estátua de José Bonifácio. Foto: gelatina, $\mathrm{p} / \mathrm{b}$. $23,4 \times 17,2 \mathrm{~cm}$. Colaborador do álbum: Augusto Malta. Fonte: Photographias D. Federal; BNDigital.

A respeito do monumento a José de Alencar (Figura 8), de 1897, que representa o romancista sentado em uma poltrona, diz Távora, retomando a ideia de uma condenação - ainda que, neste caso, uma penitência mais "confortável":

Mais feliz do que ele, é o nosso grande romancista José de Alencar, que está sentado numa cômoda cadeira de braços, e foi plantado, no dia 8 de maio de 1897, em frente ao Hotel dos Estrangeiros, mas que, depois disso foi mudado para o outro lado da antiga praça Ferreira Vianna - provavelmente para não estar embaraçando com a sua cadeira a entrada e saída dos hóspedes do hotel. $\bigcirc$ romancista, que em vida foi um homem limpo e elegante, amigo do asseio, está, depois de morto, com um pé estendido, à espera de um engraxate, que the queira limpar a bota. $\bigcirc$ gesto é inútil, porque não há engraxate que se resigne a engraxar de graça, botas de estátuas - e ainda porque não há graxa que pegue em botas de bronze. $\bigcirc$ gesto é inútil, - mas é belo, e, ao mesmo tempo, triste. A gente chega a ter dó de um homem condenado, apesar de toda a sua glória, a ficar por toda a eternidade com um pé escovado e outro por escovar... ${ }^{122}$ 


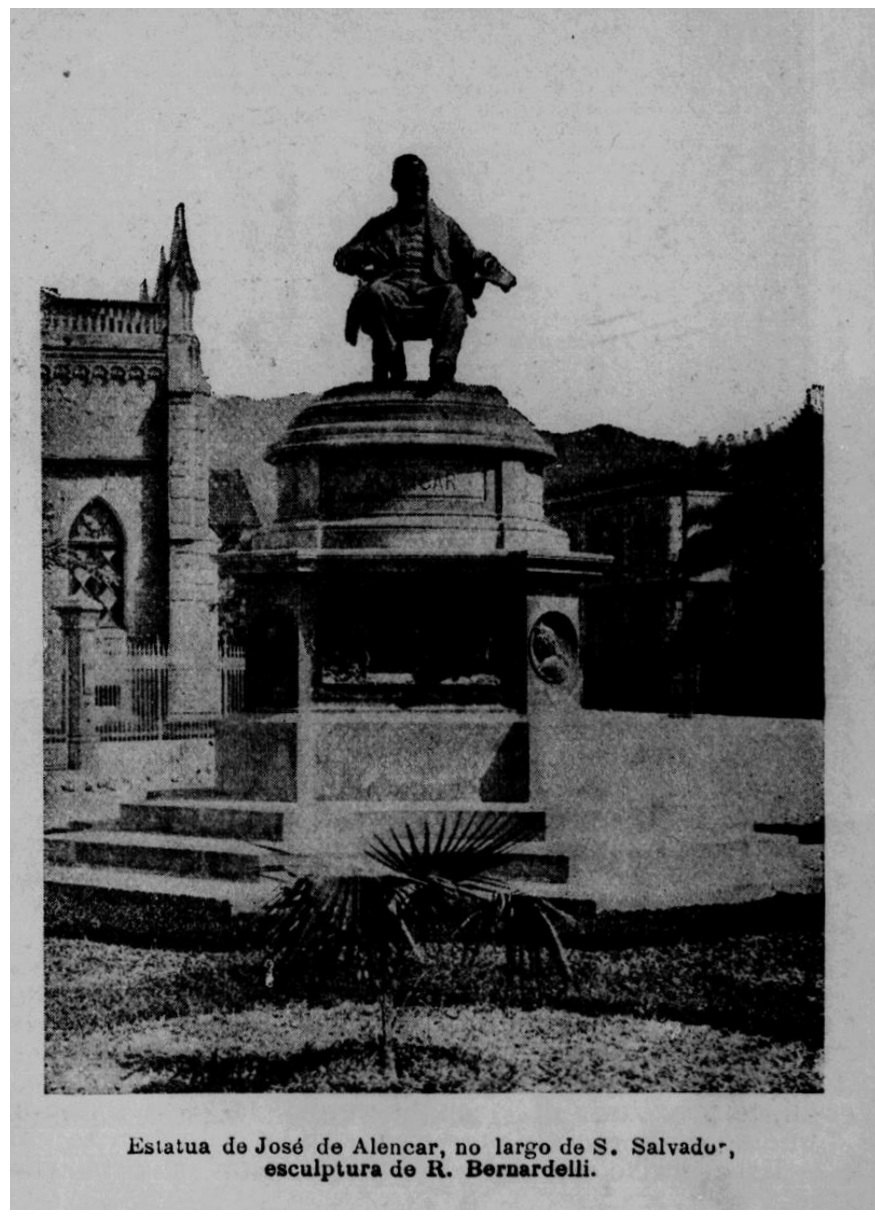

123. Ibid., grifo nosso.
Figura 8 - "Estátua de José de Alencar, no largo de S. Salvador, escultura de R. Bernardelli". Fonte: Távora (1906, p. 37); BNDigital.

A estátua, porém, alvo das maiores críticas, seja pela alegada insignificância do homenageado, seja pela sua localização e concepção, foi a do ministro Buarque de Macedo, já atacada por Bilac em 1894. Assim se manifestou Távora:

Uma outra estátua, que bastante necessidade também tem de ser escovada, é a de Buarque de Macedo, a meio caminho dos subúrbios, junto ao leito da estrada de ferro Central do Brasil. [...] $\bigcirc$ que sei é que nunca se viu uma estátua tão cheia de pó de carvão. Conheceis o motivo pelo qual erigiram aquela estátua? Aquele cidadão era ministro, e morreu pobre, tendo apenas três mil e poucos réis na algibeira... Foi uma desgraça! Não vale a pena morrer pobre, para ser condenado a ficar ali assim, comendo pó de carvão, e ouvindo o barulho ensurdecedor e perpétuo dos trens que passam, voando, bufando, num estardalhaço feroz... Eu, se algum dia for ministro, hei de tratar de morrer milionário! 123

Do mesmo modo, na Argentina, a estatuomanía foi atacada pelo prisma da concepção formal das obras, a exemplo de uma publicação na revista Caras 
124. Caras y Caretas (1902, p. 59-61). y Caretas de 1902. Após reconhecer que "la estatuomanía se halla en su apogeo", o articulista oferece, como anuncia o título do artigo, um pequeno manual para os escultores, recomendando-thes que soluções adotar e evitar a fim de que suas obras não caíssem no rídiculo:

LA MEDITACIÓN, por ejemplo, (estatuas de poetas, músicos, metafísicos, etc., etc.), no debe prestarse a ninguna confusión con el dolor de muelas, la jaqueca o el flujo de sangre de la nariz. [...]. Sucede también que EL JURAMENTO (estatuas de revolucionarios, tribunos, conjurados, etc.l, expresa más bien el gesto por el cual se asegura uno vulgarmente de la necesidad de llevar un paraguas, porque llueve. En las estatuas de militares, marinos, exploradores, etc., conviene que el brazo heroico que señala la frontera, la barricada, el enemigo que hay que vencer o el país que se debe conquistar, no pueda servir igualmente para designar la proximidad de la estación, de los water-closets o de la oficina del tramway. ${ }^{124}$

"pequeño manual para estatuarios" era acompanhado de ilustrações (Figura 9), com a mesma finalidade didática.
Figura 9 - Exemplos de posições e gestos de acordo com a ocupação do homenageado em vida: "poetas, músicos e filósofos"; "revolucionários, tribunos e conjurados"; "militares, marinheiros e exploradores". Fonte: Caras y Caretas (1902, p. 59-61); Biblioteca Nacional de España.

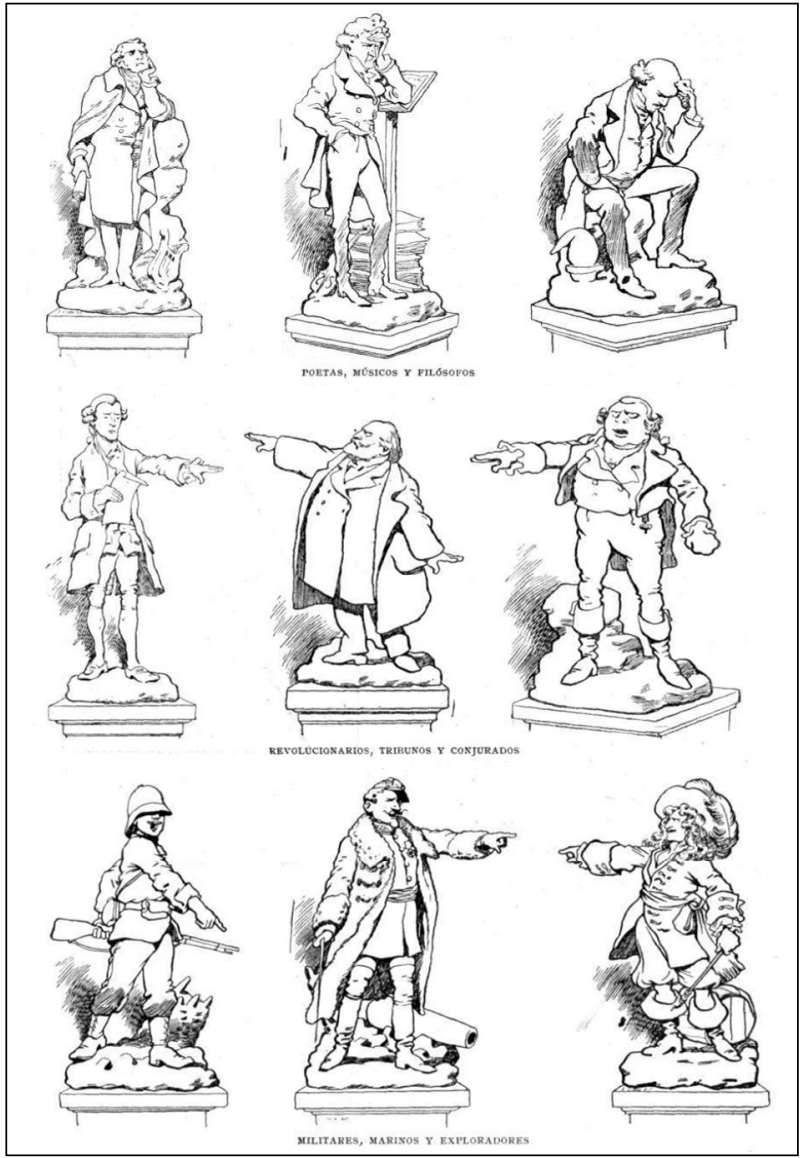


† texto e as imagens, portanto, pressupõem que muitos escultores não eram bem-sucedidos em suas obras, sendo necessário orientá-los quanto à posição, gestual, expressão facial e vestuário dos personagens representados. Conclui com uma crítica mais direta à legitimidade de algumas estátuas:

No están demás las anteriores observaciones, porque entre nosotros parecen hallarse de moda no sólo las estatuas con que intentamos inmortalizar a quienes ya eran inmortales por su historia, sino que también las que podrían llamarse auto-estatuas.

Desse modo, termina reprovando a prática das "auto-estatuas", as homenagens encomendadas a si mesmo, atribuindo a um certo senhor Garzón, de Córdoba, sua introdução no país.

\section{ÚLTIMAS PALAVRAS}

Ao longo deste artigo, discutimos como os intelectuais colaboradores dos periódicos cariocas viram a difusão de estátuas na capital brasileira e como se apropriaram do conceito de estatuomania para desenvolver suas análises, frequentemente em comparação com a França. Em alguns discursos essa estatuomania era profetizada como uma ameaça ao futuro, a partir do reconhecimento lógico de que o Rio de Janeiro não possuía um número de obras escultóricas comparável ao de Paris, buscando o autor apenas convidar seus leitores a meditar sobre o problema. Em outros, porém, mais carregados de tons dramáticos, tratava-se o termo como um problema já vigente na urbe. Seja como for, buscamos mostrar que esses autores e periódicos não fizeram uma pura e simples transplantação de uma ideia exótica, mas The deram um uso adaptado à realidade carioca de então, instrumentalizando esse conceito para torná-lo operativo no bojo das lutas políticas do momento. Denunciavase a estatuomania criticando bustos, hermas, estátuas e outras homenagens direcionadas a adversários político-partidários, a representantes de outros campos ideológicos.

Como todo fenômeno reativo, as críticas à estatuomania arrefeceram à medida que o próprio fenômeno denunciado, a multiplicação de estátuas, entrou em declínio. Agulhon aponta a Segunda Guerra Mundial como um marco importante nesse processo. Um artigo publicado na França por Albert Mousset em 1946, logo após o fim do conflito, e republicado no Brasil na revista Visão Brasileira, sintetiza bem o que se passou: 
125. Mousset apud Visão Brasileira (1946, p. 11).
Dia após dia, Paris retoma a sua fisionomia de antes da guerra, sua vida artística, sua alegria comunicativa. Mas ainda não recuperou suas estátuas. Sabe-se que muitas foram retiradas do seu pedestal por ordem dos alemães, que fundiram o bronze para a sua indústria de guerra. Entretanto a falta de metal não permite, no momento, substituir indefesas estátuas vítimas do vandalismo nazista. Até agora, a administração limitou-se a colocar em seus lugares as estátuas de pedra ou de mármore que havia guardado para as proteger contra os bombardeios [...]. ${ }^{125}$

Contudo, prossegue o autor, não era apenas culpa da intervenção alemã que alguns pedestais permaneciam vazios. Aquela ocasião era uma oportunidade para se repensar quem gozaria do merecimento de uma estátua em praça pública:

Mas não é somente a penúria do metal que impede a refundição das estátuas desaparecidas. A Direção das Belas Artes levantou a questão de saber se não é oportuno proceder agora a uma 'revisão' dos privilegiados a quem se confere uma perpetuação. Não há dúvida, naturalmente, que Victor Hugo, Voltaire, Lavoisier, devem, no mais curto prazo, voltar aos lugares que the deram a gratidão e a admiração do povo parisiense. Mas a pergunta pode ser feita a respeito das 'celebridades' que o tempo desvalorizou bastante. Perguntam-nos por exemplo, se é justo que Jules Simon e Victorien Sardou ocupem na praça da Madeleine, um lugar que dificulta o tráfego. Há que se concordar que três estátuas para Alexandre Dumas, seu pai e seu filho, na praça Malesherbes, constituem monumentos demais para uma só família. [...]. A glória, assim como a arte, tem as suas perspectivas que mudam de uma geração para a outra. Entre 1880 e 1900, Paris foi vítima de uma espécie de estatuomania. As bonitas fontes desapareceram para dar lugar a celebridades efêmeras. É chegado o momento de pôr um paradeiro a esses abusos e atentados ao bom-gosto.

\section{Mousset termina seu artigo com um apelo poético:}

Por isso é compreensível que espíritos sensatos peçam que pelo menos um dos pedestais desguarnecidos pelos alemães permaneça vazio. $\bigcirc$ peregrino poderá colocar, nele, em pensamento o personagem de sua escolha ou dos seus sonhos. 


\section{REFERÊNCIAS}

FONTES IMPRESSAS

ALTER EGO [Jayme de Séguier]. Ver, ouvir e contar. Jornal do Commercio, Rio de Janeiro, ano 88 , n. 61 , p. 1,3 mar. 1914 .

BARBIER, Auguste. La statuomanie. Satires et Chants. Paris: Éditeur E. Dentu, 1869. p. 197-202.

BILAC, Olavo. Fantasia: autores e livros. Suplemento Literário de "A Manhã": Notícias sobre Olavo Bilac, Rio de Janeiro, n. 20, p. 464, 28 dez. 1941.

BRANDES, Louis des. Gustave Pessard: Statuomanie parisienne. Études publiées par des Pères de la Compagnie de Jésus, Paris, p. 721, 1912.

CARAS Y CARETAS. Pequeño manual para los estatuarios, Buenos Aires, ano 5, n. 190, p. 5961, 24 maio 1902.

CARLYLE, Thomas. No. VII. Hudson's Statue. In: Latter-Day Pamphlets. London: Chapman and Hall, 1850. p. 216-248.

CÁVIA, Mariano de. Honores en propio honor. El Imparcial, Madrid, ano 37, n. 13.056, p. 1, 8 ago, 1903.

CEARENSE. Paris, outubro de 1884. Fortaleza, ano 39, n. 263, p. 2, 26 nov. 1884.

CHINCHOLLE, Charles. Le 24 février. Le Figaro, Paris, ano 33, n. 56, p. 2, 25 fev. 1887.

COMMERCIO DE PORTUGAL. Secção noticiosa: estatuas. Lisboa, ano 1, n. 35, p. 2, 6 ago. 1879.

D. QUIXOTE. A polícia não errou. Rio de Janeiro, ano 7, n. 336, p. 17, 17 out. 1923.

D. QUIXOTE. Elegampsias. Rio de Janeiro, ano 1, n. 9, p. 11, 11 jul. 1917. Disponível em: <https://bit.ly/3EhjqrA>. Acesso em: 25 out. 2021.

D. QUIXOTE. Elegampsias. Rio de Janeiro, ano 5, n. 237, p. 18, 23 nov. 1921. Disponível em: $<$ https://bit.ly/3BbX1dh>. Acesso em: 25 out. 2021.

DIÁRIO DA TARDE. Estátua do marechal: inauguração. Curitiba, ano 7, n. 1.772, p. 1, 19 dez. 1904. 
DIARIO DO GRAM-PARÁ. Belém, n. 280, p. 2, 11 dez. 1885.

EL PARTIDO LIBERAL. Un busto del doctor Guillotin. México, n. 2.243, p. 2, 1 set. 1892.

EL SIGLO DIEZ Y NUEVE. Ni Musset ni Balzac. México, ano 54, n. 18.047, p. 2, 16 fev. 1895.

FANTÁSIO [Olavo Bilac]. Vida de Bronze. Gazeta de Notícias, Rio de Janeiro, ano 20, n. 106, p. 1, 18 abr. 1894.

FLAMINIO, L. Os sete dias. A Notícia, Rio de Janeiro, ano 8, n. 207, p. 3, 31 ago.; 1 set. 1901.

FON-FON! Um concurso necessário: a estátua: sucesso em toda a linha. Rio de Janeiro, ano 3, n. 40 , p. 16,2 out. 1909 .

FON-FON! Um concurso necessário: Adão e Eva, novos concorrentes, o jury, apuração final, o prêmio. Rio de Janeiro, ano 3, n. 42, p. 9, 16 out. 1909.

FON-FON! Um concurso necessário: injustiça do destino. Rio de Janeiro, ano 3, n. 39, p. 7, 25 set. 1909.

FR. Artes e artistas: belas Artes. O Paiz, Rio de Janeiro, ano 40, n. 14.481, p. 2, 13 jun. 1924.

GAMA, Luiz. À forca o Christo da multidão. Tiradentes: Commemoração Annual, ano 1, p. 1-2, 21 abr. 1882.

GARCIA REDONDO. Bilhetes postais: Paris, 25 junho de 1906. A Notícia, Rio de Janeiro, ano 13, n. 173 , p. 3, 27-28 jul. 1906.

GAZETA DE NOTÍCIAS. Omnibus. Rio de Janeiro, n. 135, p. 2, 16 maio 1894.

GIL, A. Livro da porta. Revista Illustrada, Rio de Janeiro, ano 2, n. 72, p. 2, 30 jun. 1877.

IRIEL [Jayme de Séguier]. Ver, ouvir e contar. Jornal do Commercio, Rio de Janeiro, ano 68, n. 49 , p. 1,18 fev. 1890 .

JORNAL DO COMMERCIO. Notícias. Rio de Janeiro, ano 68, n. 258, p. 1, 15 set. 1890.

JORNAL DO COMMERCIO. Notícias. Rio de Janeiro, ano 81, n. 298, p. 4, 26 out. 1907.

JORNAL DO COMMERCIO. Notícias. Rio de Janeiro, ano 63, n. 233, p. 1, 22 ago. 1885. 
JORNAL DO COMMERCIO. Notícias. Rio de Janeiro, ano 63, n. 228, p. 1, 17 ago. 1885.

JORNAL DO COMMERCIO. Notícias. Rio de Janeiro, ano 81, n. 299, p. 4, 27 out. 1907.

JORNAL DO COMMERCIO. Telegramas. Rio de Janeiro, ano 62, n. 353, p. 1, 20 dez. 1883.

JORNAL DO COMMERCIO. Notícias. Rio de Janeiro, ano 68, n. 246, p. 1, 3 set. 1890.

JUNIO. Ricochetes. Revista Illustrada, Rio de Janeiro, ano 4, n. 156, p. 7, 1879.

L'INTERMÉDIAIRE des chercheurs et curieux: notes and queries français. Paris, 1911.

LA EPOCA. Madrid, ano 33, n. 10.514, p. 2, 12 out. 1881.

LA REPÚBLICA. Madrid, ano 8, n. 2.322, p. 2, 15 jul. 1891.

LAROUSSE, Pierre. Grand dictionnaire universel du XIXe siècle: français, historique, géographique, biographique, mythologique, bibliographique, littéraire, artistique, scientifique etc. : tomo XVII, $2^{\circ}$ suplemento: "statue". Paris: Administration du Grand Dictionnaire Universel, 1890.

LE FIGARO. Paris, ano 15, n. 132, p. 2, 11 maio 1868.

LE TEMPS. Paris, ano 32, n. 11.378, p. 1, 17 jul. 1892.

LE TRAIT D'UNION. México, ano 29, n. 41, p. 3, 18 nov. 1882.

LES ENTRETIENS idéalistes: cahiers mensuel d'art e de philosophie: bibliographie. Paris, p. 335-336, 25 fev. 1911.

MASCARILLE. Cartas parisienses. La Epoca, Madrid, ano 33, n. 10.523, p. 4, 21 out. 1881.

MAUL, Carlos. Mauá e Silveira Martins. Correio da Manhã, Rio de Janeiro, n. 12.491, p. 4, 9 ago. 1935.

MAUL, Carlos. Orpheu fallou às féras. In: $A B C$ : política, actualidades, questões sociaes, lettras e artes. Rio de Janeiro, ano 4, n. 180, p. 4, 17 ago. 1918.

MINAS GERAES: orgam official dos poderes do Estado. Ouro Preto, n. 242, p. 4, 13 set. 1899.

MOUSSET, Albert. Paris sem estátuas. Visão Brasileira, Rio de Janeiro, ano 8, n. 92, p. 11, 1946. 
NOLASCO, J. P. Correspondencia pariziense. Pacotilha, São Luís, ano 4, n. 281, p. 2, 3 nov. 1884.

O IMPARCIAL: diário ilustrado do Rio de Janeiro. Rio de Janeiro, ano 2, n. 148, p. 2, 1 maio 1913.

O MALHO. Rio de Janeiro, ano 6, n. 274, p. 24, 14 dez. 1907.

O PAIZ. Rio de Janeiro, ano 35, n. 12.704, p. 5, 23 jul. 1919.

PACOTILHA. São Luís, ano 4, n. 282, p. 2, 4 nov. 1884.

PARIS. Bulletin Municipal Officiel de la Ville. Paris, p. 496, 18 jan. 1912.

PERALTA, Pedro. Crônicas malucas. O Imparcial, Rio de Janeiro, ano 13, n. 4.244, p. 2, 3 ago. 1924.

PESSARD, Gustave. Statuomanie parisienne: étude critique sur l'abus des statues. Paris: Daragon, 1911.

PHOTOGRAPHIAS D. Federal: v. 1, 1911-1920. [S. l.: s. $n$.] 1 álbum (77 fotos), gelatina, pb. Disponível em: <https://bit.ly/3meUj2q>. Acesso em: 26 out. 2021.

PORTO-CARRERO, Júlio. Vão-se os heróis: o Barão de Ivinheima. Jornal do Commercio, Rio de Janeiro, ed. tarde, n. 448, 10 maio 1911, p. 2.

SANTA-ANNA NERY, Frederico. Le pays des Amazones: 1'El-Dorado, les terres à caoutchouc. Paris: Librarie Guillaumin et Cie., 1899.

SÉGUIER, Jayme. Ver, ouvir e contar. Biarritz, 28 de agosto de 1896. Jornal do Commercio, Rio de Janeiro, ano 75, n. 269, p. 1, 25 set. 1896.

SOSA, Francisco. Las estatuas de la Reforma: noticias biográficas de los personajes en ellas representados. México: Oficina Tip. de la Secretaría de Fomento, 1900. Disponível em: <https:// cutt.ly/BnppRH4>. Acesso em: 28 maio 2021.

SOSA, Francisco. Lo que significa una estatua. El Nacional, México, n. 28, p. 1-4, 15 jan. 1899.

TÁVORA, Jayme de. As estátuas do Rio de Janeiro. Leitura para todos: Magazine Mensal Ilustrado, Rio de Janeiro, ano 2, n. 4, p. 33-39, 1906.

TÉRY, Gustave. Les jours se suivent. Le Journal, Paris, n. 7790, p. 1, 24 jan. 1914.

VIEIRA, P. Cartas parisienses. Correio Paulistano, São Paulo, n. 11.700, p. 1, 13 out. 1895. 
VOLTOLINO. O cacaismo em perigo. D. Quixote, Rio de Janeiro, ano 3, n. 118, p. 23, 13 ago. 1919.

VOLTOLINO. O caso do monumento da Independência. D. Quixote, Rio de Janeiro, ano 3, n. 117, p. 23, 6 ago. 1919. Disponível em: <https://bit.ly/3pwiY4O>. Acesso em: 25 out. 2021.

WERNECK, Américo. Parallelo histórico. Tiradentes, Rio de Janeiro, ano 3, p. 3-4, 21 abr. 1884.

LIVROS, ARTIGOS E TESES

AGULHON, Maurice. Histoire vagabonde. Paris: Gallimard, 1988. v. 1.

AGULHON, Maurice. Nouveaux propos sur les statues de 'grands hommes' au XIXe siècle. Romantisme, [s. l.], n. 100, p. 11-16, 1998.

CAIRES, Daniel R. A estética nacionalista de Carlos Maul. In: ENCONTRO REGIONAL DA ANPUH UNIFESP/GUARULHOS, 24, 2018. Anais [...]. Anpuh: São Paulo. p. 1-17.

GUTIÉRREZ VIÑUALES, Rodrigo. Monumento conmemorativo y espacio público en Iberoamérica. Madrid: Cátedra, 2004.

GUTIÉRREZ VIÑUALES, Rodrigo. Un siglo de escultura en iberoamérica (1840-1940). In: GUTIÉRREZ, Ramón; GUTIÉRREZ VIÑUALES, Rodrigo (coord.). Pintura, escultura y fotografía en iberoamérica, siglos XIX y XX. Madrid: Cátedra, 1997. p. 89-151.

KNAUSS, Paulo. Do academicismo ao Arte Decó: arquitetura e escultura pública no Rio de Janeiro. Revista do IHGB, Rio de Janeiro, v. 444, p. 379-391, 2009.

KNAUSS, Paulo. A festa da imagem: a afirmação da escultura pública no Brasil do século XIX. $19 \varepsilon 20$, Rio de Janeiro, v. 5, n. 4, 2010.

MADERUELO, Javier. La pérdida del pedestal. Madrid: Circulo de Bellas Artes, 1994.

MARINS, Paulo César Garcez. O parque do Ibirapuera e a construção da identidade paulista. Anais do Museu Paulista, São Paulo, v. 6, n. 1, p. 9-36, 1999. Doi: <https://doi.org/10.1590/ S0101-47141999000100002>.

MATHEUS, Leticia Cantarela. Conexões elétricas e territorialidades no jornalismo brasileiro. Animus, Santa Maria, v. 11, n. 22, p. 272-290, 2012. Doi: <https://doi.org/10.5902/217549777050>.

MONTEIRO, Michelli Cristine Scapol. São Paulo na disputa pelo passado: o Monumento à Independência de Ettore Ximenes. 2017. Tese (Doutorado em Arquitetura e Urbanismo) Faculdade de Arquitetura e Urbanismo, Universidade de São Paulo, São Paulo, 2017. 
MONTEIRO, Michelli Cristine Scapol. Mercado e consagração: o Concurso Internacional do Monumento à Independência do Brasil. $H$-ART: Revista de Historia, Teoría y Crítica de Arte, Bogotá, n. 4, p. 79-102, 2019. Doi: <http://dx.doi.org/10.25025/hart04.2019.05>.

PACHAS MACEDA, Sofía. La enseñanza artística en Lima de la República aristocrática. Lima: Ediciones del Vicerrectorado Académico UNMSM, 2007.

PEVSNER, Nikolaus. Academias de arte: passado e presente. São Paulo: Companhia das Letras, 2005.

RAINGEVAL, Emmanuelle. Les monuments à Louis Pasteur: portraits du découvreur dans la statuaire publique. In: FAYOLLE, Azélie (dir.); RINGUEDÉ, Yohann (dir.). La découverte scientifique dans les arts. Champs sur Marne: LISAA, 2018. Disponível em: <https://cutt.ly/ Enks3Pn>. Acesso em: 2 jun. 2021.

RIBEIRO, Maria Eurydice de Barros. Memória em bronze: estátua equestre de Pedro I. In: KNAUSS, Paulo (coord.). Cidade vaidosa: imagens urbanas do Rio de Janeiro. Rio de Janeiro: Sette Letras, 1999. p. 15-28.

ROLLAND, Denis. La crise exemplaire d'un modèle européen en Amérique latine: les racines anciennes du retrait du modèle politique et culturel français. História, São Paulo, v. 27, n. 1, p. 283-344, 2008. Doi: <https://doi.org/10.1590/S0101-90742008000100014>.

SALIBA, Elias Thomé. Raízes do riso. A representação humorística na história brasileira: da Belle Époque aos primeiros tempos do rádio. São Paulo: Companhia das Letras, 2002.

SALVATORE, Ricardo. Saber hemisférico y disonancias locales: Leo S. Rowe en Argentina, 19061919. In: Los lugares del saber: contextos locales y redes transnacionales en la formación del conocimiento moderno. Rosario: Beatriz Viterbo Editora, 2007. p. 327-365.

SANTIAGO GÓMEZ, Arnulfo Uriel. La presse francophone au Mexique: signes de globalisation. História, São Paulo, v. 38, 2019. Doi: <https://doi.org/10.1590/1980-4369e2019026>.

SIMÕES JÚNIOR, Álvaro. Correspondentes estrangeiros e a repercussão do decadentismosimbolismo na imprensa carioca (1890-1893). Letras de Hoje, Porto Alegre, v. 54, n. 1, p. 19-26, 2019. Doi: <https://doi.org/10.15448/1984-7726.2019.1.33587>.

SIRINELLI, Jean-François. Os intelectuais. In: RÉMOND, René. Por uma história politica. Tradução de Dora Rocha. Rio de Janeiro: FGV, 2003. p. 231-269.

SODRÉ, Nelson Wenerck. História da Imprensa no Brasil. Rio de Janeiro: Mauad, 1999.

VANEGAS CARRASCO, Carolina. Disputas simbólicas en la celebración del centenario de la independencia de Colombia en Bogotá (1910): los monumentos a Simón Bolívar y a Policarpa Salavarrieta. Bogotá: Ministerio de Cultura, 2011. 
VELLOSO, Mônica P. As modernas sensibilidades brasileiras: uma leitura das revistas literárias e de humor na Primeira República. Nuevo Mundo, Mundos Nuevos, Paris, 2006.

VIFIAN LÓPEZ, Daniel. Escultura civil público estatal en Lima de 1852 a 1860. 2014. Tese (Licenciatura em Artes) - Universidad Nacional Mayor de San Marcos, Lima, 2014.

WEINSTEIN, Barbara. Pensando a história fora da nação: a historiografia da América Latina e o viés transnacional. Revista Eletrônica da ANPHLAC, n. 14, p. 13-29, 2013. Doi: <https://doi. org/10.46752/anphlac.14.2013.2331>.

SITES

Academia Brasileira de Letras. Biografia - Afonso Arinos. Disponível em: <https://cutt.ly/ TksnMGu>. Acesso em: 7 jan. 2021.

Academia Brasileira de Letras. Biografia - Eduardo Prado. Disponível em: <https://cutt.ly/ AksmEQy>. Acesso em: 2 fev. 2021.

Academia Brasileira de Letras. Biografia - Garcia Redondo. Disponível em: <https://cutt.ly/ WksniTG>. Acesso em: 8 jan. 2021.

Arquivo Nacional - MAPA, Memória da Administração Pública Brasileira. Biografias - Gaspar Silveira Martins, setembro de 2020. Disponível: <https://cutt.ly/PksxJgV>. Acesso em: 16 jan. 2021.

Biblioteca Nacional. FBN/Série Documentos Literários - Fantásio, pseudônimo de Olavo Bilac, 21 de outubro de 2016. Disponível em: <https://cutt.ly/xksoxY2>. Acesso em: 8 jan. 2021.

COUTINHO, Amélia. “J.J. Seabra”. Dicionário da Elite Política Republicana (1889-1930). FGVCPDOC. Disponível em: <https://cutt.ly/dEuvBM5>. Acesso em: 7 jan. 2021.

LOPES, Raimundo Helio. "PASSOS, Gervásio de Brito". Dicionário da Elite Política Republicana (1889-1930). FGV-CPDOC. Disponível em: <https://cutt.ly/gksaQKA>. Acesso em: 2 fev. 2021.

LUNA, Cristina. "MARTINS, Silveira”. Dicionário da Elite Política Republicana (1889-1930). FGV-CPDOC. Disponível em: <https://cutt.ly/mksve61>. Acesso em: 16 jan. 2021.

PINHEIRO, Luciana. "WERNECK, Américo". Dicionário da Elite Política Republicana (18891930). FGV-CPDOC. Disponível em: <https://cutt.ly/pb5nYCU>. Acesso em: 22 maio 2021.

QUADROS, Andréa Novais Soares de. "VIEIRA, Severino". Dicionário da Elite Política Republicana (1889-1930). FGV-CPDOC. Disponível em: <https://cutt.ly/Gksp6iC>. Acesso em: 2 fev. 2021. 
SILVA, Beatriz Coelho. "PRADO, Eduardo". Dicionário da Elite Política Republicana (18891930). FGV-CPDOC. Disponível em: <https://cutt.ly/Zksv4Fj>. Acesso em: 7 jan. 2021.

SILVA, Izabel Pimentel da. "COELHO, Érico". Dicionário da Elite Política Republicana (18891930). FGV-CPDOC. Disponível em: <https://cutt.ly/wEup6NB>. Acesso em: 7 jan. 2021.

ANGELO Agostini. In: ENCICLOPÉDIA Itaú Cultural de Arte e Cultura Brasileiras. São Paulo: Itaú Cultural, 15 de dez. 2017. Disponível: <https://cutt.ly/BksczUM>. Acesso em: 7 jan. 2021.

VOLTOLINO. In: ENCICLOPÉDIA Itaú Cultural de Arte e Cultura Brasileiras. São Paulo: Itaú Cultural, 14 de dez. 2017. Disponível em: <https://cutt.ly/2ksxqVK>. Acesso em: 2 fev. 2021.

Artigo apresentado em: 23/02/2021. Aprovado em: 05/07/2021. (cc) BY 